\title{
The microbial aspect of climate change
}

\author{
Himangshu Dutta ${ }^{1}$ Angshu Dutta ${ }^{2}$ \\ ${ }^{1}$ Department of Ecology and Environmental Science, Assam University, Silchar, Assam 788011, India \\ ${ }^{2}$ Department of Life Sciences, Dibrugarh University, Dibrugarh, Assam 786003, India
}

Received: 6 January 2016/Revised: 13 June 2016/Accepted: 16 June 2016/Published online: 27 June 2016

(c) Joint Center on Global Change and Earth System Science of the University of Maryland and Beijing Normal University and Springer-Verlag Berlin Heidelberg 2016

\begin{abstract}
Global warming and climate change are the most prominent issues of the current environmental scenario. These problems arise due to higher concentration of greenhouse gases in the atmosphere which exert a warming effect. Although much attention has been given to anthropogenic sources and impacts of these gases, the significance and implications of microorganisms have remained neglected. The present review brings to light this overlooked aspect (role and responses of microbes in this context) in both terrestrial and aquatic ecosystems. Through existing literature, it attempts to assess the mechanisms that cause microbes to emit and absorb greenhouse gases. The consequent effects as well as feedbacks have also been studied. It was then found that microbes play a major role with respect to climate change. Thus, microbes should never be deprived of their due importance in climate change models as well as discussions on the matter. In addition, the review also identified the necessity of proper research in this aspect as there is a lack of adequate understanding on this facet of climate change.
\end{abstract}

Keywords Climate change $\cdot$ Microbes $\cdot$ Impacts $\cdot$ Role

\section{Introduction}

World climate has remained stable for over 12,000 years, and such stability is crucially important for the existence of mankind (NASA 2015a). But the average global temperature soared up by $1.5^{\circ} \mathrm{F}$ during the last century, and it has

Himangshu Dutta

himangshu.dibru@gmail.com been projected to surge higher by additional $0.5-8.6^{\circ} \mathrm{F}$ within a period of 100 years. This is a serious issue as even subtle fluctuations in average the worldwide temperature can cause severe shifts in climate and weather (US EPA 2015a).

The microbial world holds great significance in this regard, as it an important component of carbon and nitrogen cycles and is involved in the emission and removal of greenhouse gases like carbon dioxide and methane, which in turn are responsible for climate change (Microbiology Online 2015). Photosynthetic microbes consume atmospheric carbon dioxide, whereas the heterotrophs decompose organic matter to emit greenhouse gases. The balance between the two processes is the main determinant of the net carbon flux, which differs across various ecosystems, depending upon climatic conditions like temperature. This makes microbial responses a crucial component of carbon flux on earth (Weiman 2015) as they not only lock up but also release huge amounts of carbon (Zimmer 2010). It must be highlighted here that greenhouse gases like $\mathrm{CO}_{2}$ and $\mathrm{CH}_{4}$ and $\mathrm{N}_{2} \mathrm{O}$ predominantly originate from microbes (Singh et al. 2010).

The microbial world is a crucial entity of carbon and other biogeochemical cycles, and their role with respect to climate change requires attention (Walsh 2015). However, microbes are absent from most discussions of climate change (Dupré 2008; Walsh 2015). It is in fact the lack of adequate understanding because of which microbial activity has not been considered properly in most climate change models (Dupré 2008). Therefore, the present review has been undertaken to develop an understanding about the role of microbes of both terrestrial and aquatic ecosystems with regard to climate change as well as to appreciate the 
effects of the phenomenon on the microbial world. The review attempts to highlight the significance of microbial aspect of the biosphere as a cause and "victim" of climate change.

\section{The problem}

Climate change is among the most complex global issues of the present times and encompasses scientific, economic, social, political, moral, and ethical aspects (NASA 2015a). It occurs mainly due to the effects of higher atmospheric concentrations of four greenhouse gases, viz, carbon dioxide, methane, nitrous oxide, and chlorofluorocarbons (US EPA 2016). The global warming potential (i.e., the capacity to produce warming) and atmospheric lifetime of the first three gases which are emitted due to microbial activities are 1, 12, and 298 as well as 100, 25, and 114 years, respectively (Center for Climate and Energy Solutions, USA Web site).

The severity of the problem is evident from the fact that the daily level of carbon dioxide in the atmosphere surpassed 400 ppm for the first time in human history in 2013. Such high levels used to occur, approximately three to five million years ago during the Pliocene era (NASA 2015a). With climatic changes, adaptability will be required, which will be difficult to achieve under elevated rates of change (NASA 2015a). The consequences of global warming are likely to be more intensified at high northern latitudes, where temperature elevation would be about twice the global average (Ruess et al. 1999).

\section{Significance of terrestrial and aquatic ecosystems}

The soil ecosystem is a huge pool of dynamic carbon and is an important determinant of the trends of climate change (Raich and Potter 1995). Approximately $3.1 \times 10^{5} \mathrm{~kg}$ (3100 Pg) of carbon is present in soil which is more than two-thirds of the total terrestrial carbon (Schlesinger and Andrews 2000; Hibbard et al. 2005; Davidson and Janssens 2006). In other words, terrestrial soil stores more carbon than the atmosphere and vegetation combined (Schlesinger 1997; Jobbagy and Jackson 2000). The soil-atmosphere exchange of carbon dioxide $\left(\mathrm{CO}_{2}\right)$ is a major component of the global carbon (C) cycle (Raich and Potter 1995), and about $10 \%$ of the atmospheric carbon dioxide of the atmosphere passes through soil on an annual basis (Raich and Potter 1995). The terrestrial surface flux of carbon dioxide, which generates emissions of $5000-7500 \mathrm{~kg}$ (50-75 Pg) of carbon per year, is an important contributor to global carbon cycling (Raich and Schlesinger 1992). It must be added that about $1.2 \times 10^{14} \mathrm{~kg}$ (120 billion tons) of carbon is taken up by primary production every year by autotrophic soil microbial, whereas soil heterotrophic microbes cumulatively emit about $1.19 \times 10^{14} \mathrm{~kg}$ (119 billion tons) of carbon (Singh et al. 2010).

The aquatic ecosystems are no less relevant to the issue of climate change. The oceans act as a sink of $\mathrm{CO}_{2}$ and hence are known as the biological pump (Glöckner et al. 2012). The upper oceanic layer is the boundary where $\mathrm{CO}_{2}$ and other greenhouse gases have accumulated in course of decades, and the deep ocean is the most formidable carbon storehouse in the world (Gruber et al. 2002; Sarmiento and Gruber 2002). In the ocean ecosystem, approximately $6 \times 10^{12} \mathrm{~kg}$ (60 gigatons) of carbon is annually processed by microbes (Field et al. 1998). The oceans along with the soil ecosystem constitute a global carbon sink for about $3 \times 10^{12} \mathrm{~kg}$ ( 3 billion tons) of carbon and absorb $40 \%$ of carbon dioxide emission from fossil fuel burning (Singh et al. 2010).

\section{Relevance of microbial world to the problem}

The activities of microorganisms have been critical in the determination of atmospheric concentrations of greenhouse gases such as carbon dioxide $\left(\mathrm{CO}_{2}\right)$, methane $\left(\mathrm{CH}_{4}\right)$, and nitrous oxide $\left(\mathrm{N}_{2} \mathrm{O}\right)$ in the course of earth's history (Singh et al. 2010). Microbes have been producing and removing greenhouse gases since their evolution in the ocean more than 3.5 billion years ago and after their movement to land about 2 billion years ago (Zimmer 2010). In fact, these are responsible for the main processes causing greenhouse gas fluxes between soils and the atmosphere (Conrad 1996; Falkowski et al. 2008) and contribute immensely to terrestrial $\mathrm{CO}_{2}$ emissions (Melillo et al. 2002, 2011). It must be mentioned here that the average worldwide concentration of $\mathrm{CO}_{2}$ in the atmosphere was about $380 \mathrm{ppm}$ in 2005, which exceeded the earlier maximum concentration for the past 650,000 years by about 80 ppm (IPCC 2007a). Microorganisms have resulted in several changes in world climate which has also, in turn, influenced them (Zimmer 2010). In fact, several microorganisms are likely to be affected by climate change, which can lead to environmental, economic, and societal impacts (French et al. 2009).

\section{Role of microbes in climate change}

\subsection{Role of terrestrial microbes}

\subsubsection{Production of carbon dioxide and methane}

The amount of atmospheric carbon produced due to soil microbial decomposition is 7.5-9 times of what is released 
due to anthropogenic emissions worldwide annually (Crowther et al. 2015). In fact, through the decomposition of plant organic matter, microorganisms in soil release $5.5 \times 10^{12} \mathrm{~kg}$ ( 55 billion tons) of carbon dioxide every year which is eight times more than that by humans (Zimmer 2010). This has tremendous influence on carbon cycle-climate feedback, on the basis of which the Intergovernmental Panel projects climate change. Soil biotic interactions are thus significant because they are crucial in mediating soil microbial feedbacks to climate change (Crowther et al. 2015). However, microbial organic matter decomposition is highly sensitive to climatic trends (Crowther et al. 2015).

Worldwide emission of $\mathrm{CH}_{4}$ is more directly dependant on microorganisms as compared to $\mathrm{CO}_{2}$ (Singh et al. 2010). Microbes are, in fact, responsible for about $85 \%$ of world methane release (Zimmerman and Labonte 2015). In this context, spongy bog soils need a special mention, where a large number of microbial genes and proteins are responsible for methane emission. This can be exemplified by the enzyme methylcoenzyme $\mathrm{M}$ reductase, which is responsible for the transformation of carbon dioxide into methane. Warming trends could drive many such local microbes to release larger amounts of methane (Svoboda 2015a).

Microorganisms consume about $60 \%$ of methane produced across the world (Zimmerman and Labonte 2015). In fact, methane-consuming microorganisms are capable of removing atmospheric methane even at very low concentrations and occur in both land and sea (Zimmerman and Labonte 2015). In this way, microbes contribute toward controlling methane emission which in turn regulates climate change. In this regard, mention can also be made of the microbes of native prairie grasslands, which play the significant role of stabilizing carbon flux. However, altered precipitation patterns arising due to climate change affect these microbes. This in turn has the potential to impose major consequences on the carbon balance in such ecosystems by affecting soil carbon storage (Weiman 2015).

\subsubsection{The issue of permafrost}

In the context of climate change, the permafrost of the poles, which is the biggest terrestrial reservoir of carbon compounds (Weiman 2015), needs a special mention. Even though the permafrost occupies $9 \%$ of the landmass of the earth, it contains $25-50 \%$ of global soil organic carbon (European Commission 2015). Around $1.7 \times 10^{15} \mathrm{~kg}$ (1700 gigatons) of carbon remain captured in permafrost, whereas the atmosphere contains approximately $8.50 \times 10^{14} \mathrm{~kg}$ (850 gigatons) (Atkin 2015). In fact, North American and Siberian tundra has stored carbon for the past 11,000 years since time when the glaciers retreated at the end of the last Ice Age (Zimmer 2010).

However, increase in temperature, on account of climate change, initiates the melting of the inert permafrost layers. Consequently, the dormant microbial community within these structures is activated, and biotic activities such respiration, fermentation, and methanogenesis are triggered (Weiman 2015). Bacteria present in the thawing soil layer begin producing several proteins and enzymes that break down large carbon molecules like plant cellulose into simpler sugars that serve as source of energy for the bacteria (Svoboda 2015a). As thawing proceeds, the soil begins transitioning more into decomposition (Svoboda 2015a). These processes lead to the conversion of soil carbon into greenhouse gases (e.g., carbon dioxide and methane) (Weiman 2015).

Soil microbes utilize either acetate produced by plants, or carbon dioxide and hydrogen to acquire energy and produce methane in the process. The initial methane flux arises from the latter pathway. However, as the frozen soils are converted gradually into wetlands, the former arises as the preferred pathway (University of Arizona 2014). As the Arctic becomes warmer and drier, the permafrost microbes are initially expected to produce carbon dioxide. But as the environment further changes, the microbes would release methane (Atkin 2015). Thus, as the Arctic and Alpine tundra heat up because of climate change, larger amounts of methane are emitted from permafrost soils, mainly due to the activities of methaneproducing archaea. However, these processes and associated methane-consuming sources have not been precisely understood (Dupré 2008). Therefore, Arctic carbon is regarded as potential symptom as well as driver of global warming (European Commission 2015). It is currently a serious issue because the permafrost of Greenland has been activated with the warming up of the climate (Atkin 2015). Approximately $1.20 \times 10^{14} \mathrm{~kg}$ (120 gigatons) of carbon (without considering microbes) has been projected to be emitted from thawing permafrost by 2100 , and this would increase the average temperature by $0.29^{\circ}$ across the globe. If the climate worsens even further, total permafrost emissions would almost double. It is a highly significant issue because these emissions arising from permafrost are irreversible (Atkin 2015). The microbe Methanoflorens stordalenmirensis plays crucial in this aspect since it releases huge amounts of carbon trapped in Arctic permafrost as methane. This organism plays an important role in deciding the fate of such ecosystems (Zolfagharifard 2014). The species was discovered in permafrost soils in northern Sweden that had thawed on account of rising temperatures (University of Arizona 2014). Figure 1 illustrates the issue of permafrost. 


\subsubsection{The issue of agricultural lands}

Huge quantities of $\mathrm{N}_{2} \mathrm{O}$ are produced due to microbial nitrification and denitrification from agricultural lands which predominates as a source of nitrous oxide. This accounts for more than one-third among the sources of the greenhouse gas (IPCC 2007a). In fact, for the deposition of every $1000 \mathrm{~kg}$ (i.e., 1 ton) of reactive nitrogen (mainly fertilizer), $10-50 \mathrm{~kg}$ is emitted as $\mathrm{N}_{2} \mathrm{O}$ (Singh et al. 2010). According to Tilman et al. (2001), in 2000 there were $1.5 \times 10^{6} \mathrm{~km}^{2}\left(1.549 \times 10^{9} \mathrm{ha}\right)$ of croplands, $3.479 \times 10^{6} \mathrm{~km}^{2}\left(3.479 \times 10^{9} \mathrm{ha}\right)$ of pastures, and $2.809 \times 10^{5} \mathrm{~km}^{2}\left(2.809 \times 10^{8}\right.$ ha $)$ of irrigated lands all over the world, and these were projected to increase by 18.5 , 13.4, and $47.1 \%$ by 2050, respectively. Agricultural soils are central to global carbon and nitrogen cycles, and it has been found that cultivated soils under conventional tillage practices release approximately ten times more nitrous oxide than forest soils (Robertson et al. 2000). Avrahami and Conrad (2003) observed that the proportion of $\mathrm{N}_{2} \mathrm{O}$ associated with nitrification decreases at elevated temperatures. However, temperature does not affect denitrifying enzyme activity (DEA) (Barnard et al. 2004). It is also a fact that although soil microbial processes release greenhouse gases (e.g., $\mathrm{CO}_{2}, \mathrm{~N}_{2} \mathrm{O}$, and $\mathrm{CH}_{4}$ ), soil also acts as sink for carbon in agricultural lands (Cole et al. 1996).

\subsection{Role of aquatic microbes}

About $93 \%$ of the world's carbon dioxide is stored in oceans, which cycle approximately $9 \times 10^{13} \mathrm{~kg}$ (90 billion tons) of carbon dioxide per year, whereas approximately $6 \times 10^{12} \mathrm{~kg}$ ( 6 billion tons) is of anthropogenic origin (Stewart 2003). The mechanics of the oceanic carbon cycle is mostly dominated by micro-, nano-, and picoplanktons, including bacteria and archaea (Stewart 2003). Enormous populations of photosynthetic microorganisms occur in oceans, especially in polar regions (e.g., Arctic sea ice), and these remove formidable quantities of atmospheric carbon. In fact, microbes in the ocean have sequestered approximately one-fourth of anthropogenic carbon dioxide released since 1960 (Weiman 2015). In addition, ocean waters accommodate a huge population (approximately $4 \times 10^{30}$ ) of viruses, which could lyse up to $50 \%$ of oceanic bacteria every day. In this way, they significantly affect global geochemistry by causing alterations in the accumulation and respiration of organic material, an important factor of climate change (Suttle 2007).

Methanotrophic bacteria buffer the effect of huge amounts of $\mathrm{CH}_{4}$ emitted under some environments (Singh et al. 2010). For instance, they consume huge amounts of methane arising not only from marine sediments, but also abrupt well blowouts like the Deepwater Horizon spill (Zimmerman and Labonte 2015). The marine environment is in fact a formidable source of release of methane to the atmosphere as there is a constant leaking of this greenhouse gas from the holes on the ocean floor. However, every such methane seep has its own unique community of methaneeating microbes as there is no universal species that is distributed throughout the entire deep sea at these areas. Such microbial populations remove about $75 \%$ of the

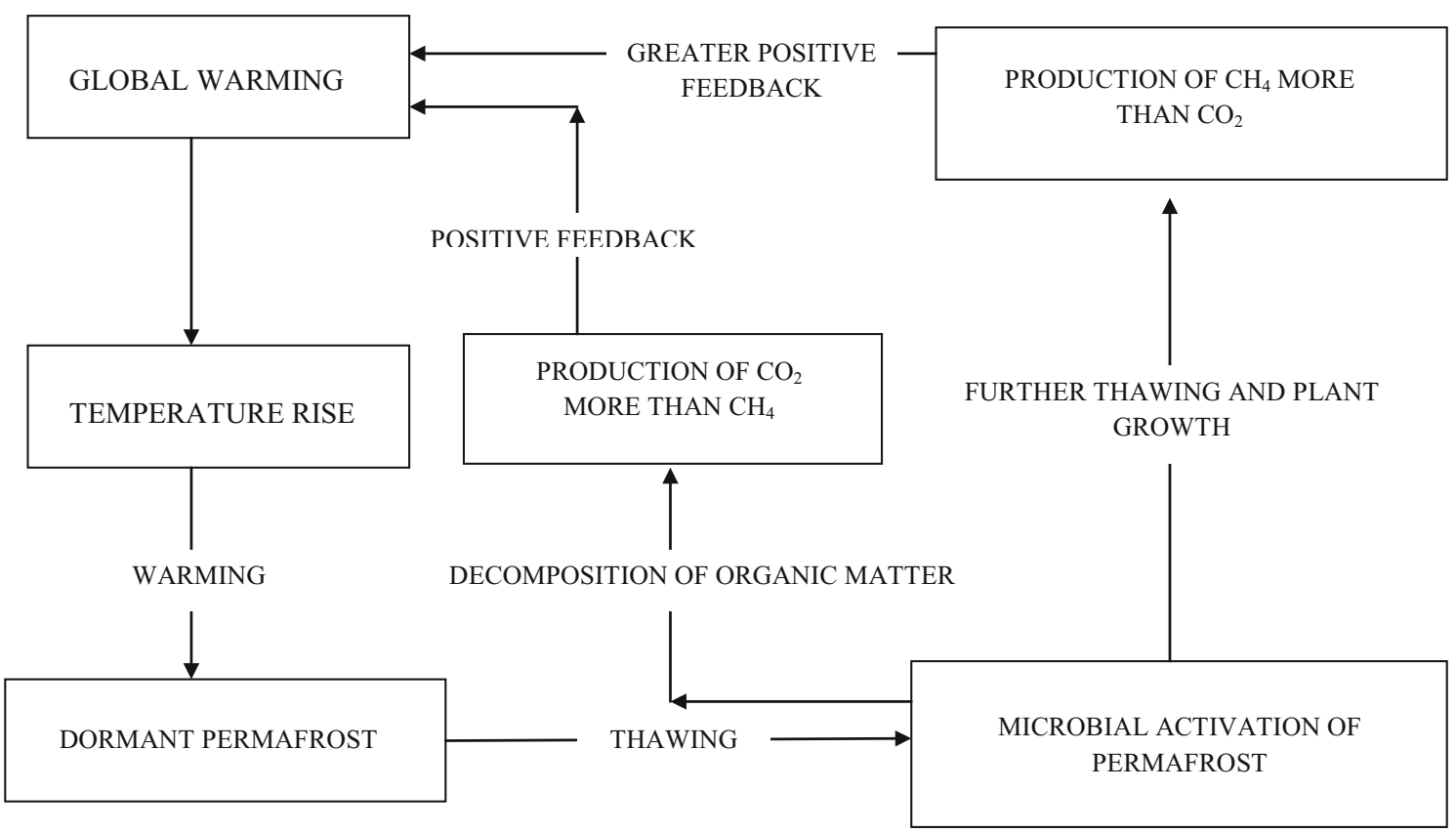

Fig. 1 Positive feedback between global warming and thawing of permafrost 
arising methane before the gas enters the atmosphere. These organisms thus provide an important service in maintaining the climate by reducing the emission of greenhouse gases (Trinastic 2015).

Methanogenesis by anaerobic archaea in wetlands, oceans, rumens, and termite guts are predominantly responsible for natural emissions ( $\sim 250$ million tons, i.e., $2.5 \times 10^{11} \mathrm{~kg}$ annually) of $\mathrm{CH}_{4}$ (Singh et al. 2010). In this regard, landscape characteristics are important determinants of microbial greenhouse gas emissions and carbon storage. For instance, saltier wetlands harbor microbial communities that release lesser quantities of methane, in comparison with areas where there is an active flow of water (Svoboda 2015b). Another significant factor is the state of water bodies. Wetlands which have been restored are inhabited by microbial communities that produce methane at higher rates than those which have remained undisturbed. Greater plant growth in restored wetlands is likely to speed up biological processes that emit methane (Svoboda 2015b). The balance of methane on earth depends upon the activity of three groups of microbes, viz, (1) methanogenic (methane-producing) microbes like Archaea which thrive in sediments under seabed, freshwater lakes, and wetlands as well as in deep in oxygen-free soils; (2) methanotrophic archaea (methane consumers) that exist in marine sediments and remove approximately $90 \%$ of ocean methane and (3) methane-oxidizing bacteria of soil and water that use oxygen to consume methane (Zimmerman and Labonte 2015).

However, microorganisms can also stimulate positive feedbacks for climate change. This is evident by the fact that when Arctic sea ice melts, the dark surfaces of marine phytoplanktons absorb larger proportions of solar radiation, which could accelerate the warming of waters bodies up to 20 percent more than what has been predicted by current climate models. Under worst scenarios, additional $10 \%$ of sea ice could disappear, and there could be about 50 more ice-free days during summers (Piotrowski 2015).

In addition to above, oceans also affect climate by releasing huge quantities of dimethyl sulfide (DMS). It is emitted due to bacterial and eukaryotic degradation of dimethylsulfoniopropionate (DMSP) produced by some microalgae for osmoprotection. The compound (DMS) is converted to an aerosol form of sulfate which later acts as cloud condensation nuclei and enhances cloud albedo, resulting in greater reflection of sunlight that exerts a negative effect on the algae (Glöckner et al. 2012). Consequently, the growth of microalgae and hence the production of DMSP are affected; as a result, lesser amounts of DMS would be emitted. DMS could also act as transporter of sulfur from the oceans to the land, causing precipitation of sulfuric acid with rain. As a result, rock weathering would be enhanced, thereby causing transport of nutrients from land to oceans and enhancing microbial (Glöckner et al. 2012).

\section{Climate change mechanisms of action}

Climate change is characterized by changes in temperature, precipitation, and length of the seasons (Smith et al. 2008). Thus, its mechanism of action is manifested mainly through fluctuations in moisture and temperature.

\subsection{Mechanisms acting on terrestrial microbes}

Climate change factors such as elevated levels of atmospheric $\mathrm{CO}_{2}$, altered temperature patterns, and warming have direct and indirect consequences on soil microbial communities (Castro et al. 2010). In fact, climate change brings about modifications in a number of factors simultaneously, due to which complex changes take place in the terrestrial microbial community (Castro et al. 2010). Such bulk changes under the influence of climate change can have significant impacts not only on the microbial world but also on plants and soil carbon balance (Classen et al. 2015a, b). However, interactions among various variables of climate change factors can also be selective toward particular soil microbes, leading to changes in community could eventually decide the future state of ecosystems (Castro et al. 2010).

\subsubsection{Changes in diversity}

Climate warming exerts abiotic stress and can cause alterations in soil microbial diversity and their processes (Shade et al. 2012). Various microbial groups are specific in their preference of temperature ranges for growth and activity; consequently, increased temperature can have impacts on the composition of the microbial community (Fierer and Schimel 2003; Singh et al. 2010). With temperature elevation, the rate of microbial processing, turnover, and activity is accelerated. As a result, shifting of microbial community occurs in favor of the species which are better adapted to higher temperatures and have accelerated rates of growth (Castro et al. 2010). This can be exemplified by the impact of climate change on two key topsoil cyanobacteria, viz, Microcoleus vaginatus and $M i$ crocoleus steenstrupii, in arid topsoils of western USA. The latter, which is thermo-tolerant, has been found to outcompete and even replace the former which is psychrotolerant as global temperatures surge. These bacteria are critical for maintaining the microbial population of the topsoil, the characteristics of which are crucial for controlling soil erosion (DiGregorio 2015). Thus, it is precise that climatic change modifies the relative abundance as 
well as function of soil microbial communities because microbes differ in terms of physiology, temperature sensitivity, and growth rates. This in turn directly affects the regulation of the specific processes which are carried out by these organisms (Classen et al. 2015a, b). Such alterations in the composition of microbial community, triggered by warming, can also cause the depletion of available substrate (Schindlbacher et al. 2011). In this regard, it must be added that abundances of both fungi and bacteria are likely to be affected by warming (Schindlbacher et al. 2011). This holds great significance because ecosystem functions such as nitrogen fixation, nitrification, denitrification, and methanogenesis are regulated by specific microorganisms. Consequently, alterations in their relative abundances directly impact the rate of these processes. However, some processes that take place at a coarser scale (e.g., nitrogen mineralization) are more affected by abiotic factors such as temperature and moisture compared to microbial community composition as a diversity of organisms drives these processes (Classen et al. 2015a, b).

\subsubsection{Physiological changes}

Warming raises microbial maintenance, leading to an increase in microbial maintenance demand (respiration per biomass) increases (Anderson and Domsch 2010). Consequently, warming accelerates soil microbial activity which elevates soil respiration (Rustad et al. 2001; Wu et al. 2011). Alterations in soil respiration are also triggered by changes in microbial community structure (Balser et al. 2006), substrate availability (Eliasson et al. 2005; Davidson and Janssens 2006), plant litter quality and quantity (Rustad et al. 2001), and relative abundance of available carbon (Fierer et al. 2005) brought about by temperature elevation. Thus, it is understood that global changes like temperature increase can directly alter the rates of respiration of soil microbes because of the temperature sensitivity of microbial metabolism and the activities they carry out (Classen et al. 2015a, b). However, changes in the composition microbial community and adaptations which determine an increase in soil respiration are unlikely to occur until other variables like substrate and moisture become limited or composition/structure in forest stand are altered (Schindlbacher et al. 2011). Soil respiration is positively correlated with temperature and could be suppressed at low or high moisture levels (Luo and Zhou 2006). It is also sensitive to soil temperature and moisture fluctuations caused due to changes in precipitation (Aanderud et al. 2013). Figure 2 illustrates the overall effect of climate change on soil microbes.

Another important entity to be considered in this regard is enzyme activity. It must be mentioned here that microorganisms increase nutrient allocation for enzyme production (to acquire greater nutrients required) to sustain increased maintenance costs with warming (Wang and Post 2012; Wang et al. 2013). In fact, climate change leads to short-term changes in enzymatic activity driven by thermodynamics (Trasar-Cepeda et al. 2007) as well as longterm changes in enzyme pools due to direct and indirect impacts on microbial production of enzymes and on turnover rates (Schimel et al. 2007). Fluctuations in temperature and moisture affect the overall and relative rates of enzyme production due to effects on enzyme efficiency, substrate availability, and microbial efficiency. When the activity of the extant enzyme pool is elevated by soil temperature increase and substrate is available, microbes may allocate fewer resources to enzyme production if microbial biomass remains unchanged (Allison and Vitousek 2005). It must be noted that temperature sensitivity of N-degrading enzymes is lower than C-degrading enzymes (Wallenstein et al. 2009, 2012; Stone et al. 2012). A related aspect is substrate temperature sensitivity, which depends upon several factors like level of moisture, oxygen availability, and accessibility (sorption and aggregate status) (Davidson et al. 2006). Microbial growth and substrate utilization are relevant for explaining temperature dependence of soil respiration (Larionova et al. 2007). In addition, soil microbial activity also varies with soil type, which could be a significant factor in this regard. It must be noted that microbial activity is low in volcanic ash soil due to the properties of allophone (Joa et al. 2010). The significance of temperature with regard to respiration, turnover of microbial biomass, and soil organic matter can be exemplified by the fact that the same are higher in tropical soils compared to temperate soils (Joergensen 2010).

\subsubsection{Mechanisms acting through plants}

Plants are important biotic factors that play an important role in this regard. They alter the rates of soil microbial respiration by releasing carbon substrates through roots (Cardon and Gage 2006; Scott-Denton et al. 2006), modify soil moisture and temperature through transpiration and by providing shade (Lauenroth and Bradford 2006) as well as by altering the amount of rainfall that reaches the soil. Moreover, the composition of vegetation determines the quality and type of plant remains, i.e., organic matter that reaches the soil and consequently the soil respiration. This can be illustrated by the difference in respiration between soils under deciduous and evergreen forests (Rey and Jarvis 2006). The quality of the organic matter in soils of similar origin depends upon the type of vegetation cover as well as anthropogenic land use and management (Guntiñas et al. 2013). This has tremendous importance as availability of readily decomposable carbon and temperature-dependent 


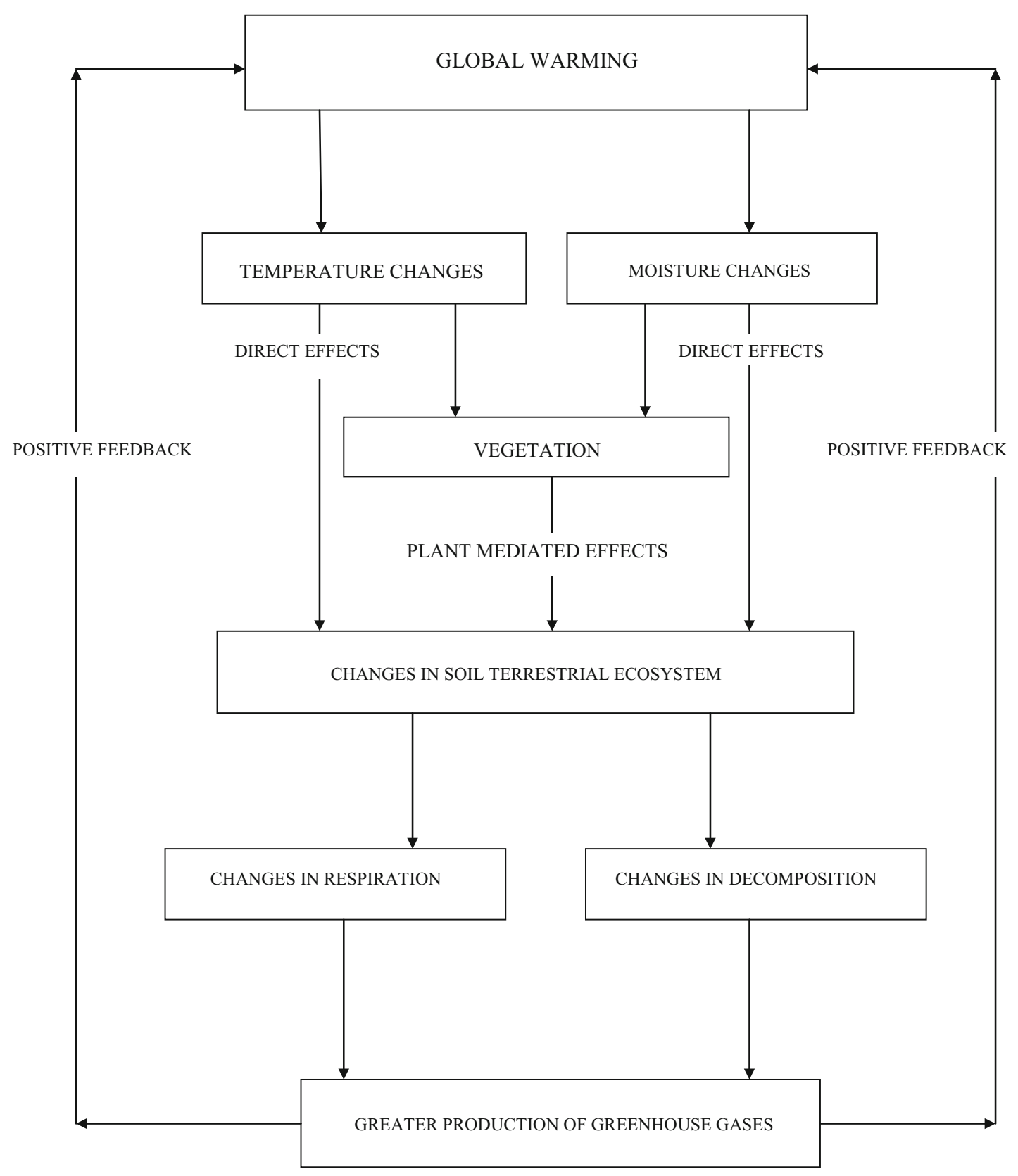

Fig. 2 Positive feedback between global warming and soil microbial effects

substrate release are the main determinants of temperature sensitivity of soil respiration (Larionova et al. 2007). Differences in temperature sensitivity of soil organic matter decomposition result in severe uncertainties in $\mathrm{C}$-cycle models (Larionova et al. 2007).

\subsubsection{Moisture fluctuations}

In addition to temperature, climate change also exerts it consequences on soil ecosystem through fluctuations in moisture, which is a master variable that has a profound effect on patterns of soil respiration in several terrestrial ecosystems (Aanderud et al. 2011). Microbial activity and hence decomposition is affected by several factors that vary with water and moisture content such as water movement, gas, and solute diffusion as well as survival and motility of microorganisms (Rodrigo et al. 1997; Luo and Zhou 2006). Moisture can also suppress microbial activity in several environments such as saltwater and soils. Low water availability lowers intracellular water potential and in this way reduces hydration and activity of enzymes (Stark and Firestone 1995). Soil moisture can also have 
intense effects on the dynamics and emission of $\mathrm{CO}_{2}$ (Aanderud et al. 2011). This can be illustrated by the fact that in grasslands, soil moisture and temperature mainly regulate soil respiration, which in turn determines carbon dioxide $\left(\mathrm{CO}_{2}\right)$ feedbacks between soils and the atmosphere (Aanderud et al. 2011).

\subsection{Mechanisms acting on aquatic microbes}

Elevation in global temperature increases sea surface temperature (Glöckner et al. 2012). Consequently, global warming has been projected to increase the temperature of surface oceanic waters by $2-6{ }^{\circ} \mathrm{C}$ during this century (Sarmento et al. 2010). In fact, sea surface temperature has been predicted to increase between $1.18{ }^{\circ} \mathrm{C}$ (under conditions of low $\mathrm{CO}_{2}$ emission) and $6.48{ }^{\circ} \mathrm{C}$ (under conditions of high $\mathrm{CO}_{2}$ emission) (Meehl et al. 2007). In-shore sea temperatures are likely to vary by $2{ }^{\circ} \mathrm{C}$ above or below average, with a trend toward higher temperatures. (Hiscock et al. 2001). This can have widespread effects as temperature has a direct impact on water chemistry and thereby exerts primary influence on biological activity and growth (The USGS Water Science School 2015). It could in fact be selective for the existence of specific marine microorganisms through its effects on respiration and production (Glöckner et al. 2012).

Microbial abundance is inversely related to abundance temperature in aquatic ecosystems (Brown et al. 2004). Warming gives rise to oxygen-depleted dead zones in deep lakes by hampering air exchange, and such sites are unable to support life (Union of Concerned Scientists 2011). Viscosity is the most prominent property of water that depends upon temperature. Its variation has significant effects on the carrying capacity and growth rates of consumers, as well as the average density of the top predators (Beveridge et al. 2010). The density of water is also affected by temperature fluctuations, which in turn has impacts on stratification and currents and consequently the transport of microbial nutrients (Glöckner et al. 2012).

The global biogeography of phytoplankton depends mainly upon temperature and other environmental factors that select species according to optimal growth potential (Huertas et al. 2011). At higher temperature, the rate of multiplication of marine phytoplankton and cell density are higher and initiation of decay is earlier (CMFRI 2009). Phytoplankton survival under elevated temperature depends upon phenotypic acclimation, mutation, and selection. Microorganisms can adapt with unfavorable conditions as a result of phenotypic acclimation, resulting solely from physiological modifications. When physiological capacity is surpassed, survival is determined by genetic adaptation, supported by mutations and subsequently followed by selection (Sniegowski and Lenski 1995). The resultant consequences could be significant because (1) marine microbes account for 98 percent of global oceanic biomass oceans, (2) they supply over half of world oxygen and are major processors of greenhouse gases, and (3) they have the potential to mitigate the effects of climate change (Vivekanandan 2016). However, global warming will benefit smaller phytoplanktons in aquatic environments as small-sized microbes have greater tolerance to increased temperature and the resulting environmental selection for smaller primary producers would have profound implications for biogeochemical cycles and food web structure (Huertas et al. 2011). The proper understanding of this aspect is complicated by the fact that exact thresholds are not known for most of the marine microbes which makes assessment of temperature sensitivity of microbes difficult (Vivekanandan 2016).

Temperature affects growth rates in both marine and freshwater microalgae (Suzuki and Takahashi 1995; Butterwick et al. 2005). These organisms exhibit quick responses to changes in climate. Such changes are first manifested through alterations in algal species in the aquatic environments (on the short timescale), whereas on longer timescales, algal assemblages can be altered (McCormick and Cairns 1994). In fact, effects on algae have been instrumental in understanding the past as well as detecting anomalies in the present (Irish Marine Life Website). For instance, alterations in pigmentations in red algae are indicative of irradiance conditions and hence are useful indicators of climate change (Irish Marine Life Website).

Due to increased temperatures, metabolism and growth are likely to increase in some microalgal species. Among other intolerant species, competitions could be altered at the species and community levels. On the other hand, elevated $\mathrm{CO}_{2}$ levels can cause changes in competition and composition in algal community. The resultant consequence would be the composite effect of complex interactions between climate change and other environmental factors (Beardall and Raven 2004). An important consequence is on the distribution of algal species. In this regard, mention can be made of the algal species Fucus distichus distichus, the distribution of which is to the north of $13^{\circ}$ isotherm in Britain. An increase in summer sea temperature by $1-2{ }^{\circ} \mathrm{C}$ can cause the disappearance of this species in Britain by shifting the $13^{\circ}$ isotherm to the north. However, in this regard, day length could be a critical factor. The distribution of Lithothamnian glaciale which has a southern limit at Lundy in Scotland and Galway in Ireland can also be changed with temperature rise by $2{ }^{\circ} \mathrm{C}$ or more (Beuchel et al. 2006).

Heterotrophic bacteria play the most crucial role in marine microbial food web, and their metabolism and interactions are regulated by temperature (Sarmento et al. 
2010). It is in fact an important factor in determining the activity of bacterioplankton in aquatic systems, which play a major role in biogeochemical cycles because of their large numbers and high turnover rates (Staroscik and Smith 2004). Under lower water temperatures, bacteria are unable to completely utilize the organic carbon in the environment (Nedwell 1999). It must be noted here that the impacts of temperature on bacterioplankton carbon metabolism are both complex and diverse and have not been properly understood (Apple et al. 2006).

In temperate coastal areas under low temperatures, it is temperature and not the availability of substrate which limits bacterial productivity (Staroscik and Smith 2004). In fact, there is higher degree of correlation between bacterial activity and temperature in coastal and estuarine environments than freshwater and open ocean locations (White et al. 1991). Variations in water temperature have consequences on both abundance and production in bacteria (Staroscik and Smith 2004). In oceans, warming increases bacterial respiration, bacterial losses to their grazers (resulting bacterial-grazer biomass flux within the microbial food web), and bacterial production under conditions of resource availability) (Sarmento et al. 2010). The rate of predation on grazers is expected to surge with temperature in proportion to the body mass of predators (Emmerson and Raffaelli 2004; Brose et al. 2006). However, as a whole, temperature elevation in oceans is likely to favor heterotrophic bacterioplankton over phytoplankton, leading to greater heterotrophic production growth (Sommer and Lengfellner 2008; Hoppe et al. 2008)

Bacterial communities are more intensely affected by temperature in areas where water temperatures remain low only in winter (Sieburth 1967; Simon and Wünsch 1998). For poikilothermic organisms, like bacteria, the basal metabolic rate increases with increasing temperature and consequently the energy demand grows. Under conditions of low food availability, increased temperature exerts negative effect on growth because basal metabolism is accelerated even though the required energy is unavailable. However, when food resources are surplus, organisms have additional energy, which can be utilized for biomass growth. Under such situations, growth increases up to a certain point where enzymes and cellular activities are halted. This can lead to changes in bacterial community composition, increment in growth rates, and shortening of response time (Degerman et al. 2013). In fact, microbial metabolic rates nearly double with every $10{ }^{\circ} \mathrm{C}$ increase in temperature (Morita 1974), and water temperature has consequences on bacterial response to nutrients, especially during storm events (Adams et al. 2015).

\section{Impacts of climate change on microbes}

The responses of microbes are exhibited vividly toward biotic and abiotic factors (Kardol et al. 2010), and hence climate change impacts are precise in case of these organisms. In fact, soil microorganisms are highly dynamic and react rapidly to environmental conditions (Joergensen 2010). However, temporal and spatial scales determine which environmental factor is most important (Savage et al. 2009). The effects of warming on microbial processes are expected to be greatest at higher latitudes (Davidson et al. 2006; The Core Writing Team 2007).

\subsection{Impacts on terrestrial microbes}

\subsubsection{Effects of temperature}

Although a number of factors such as climate, the parent material, the age and texture of soil, topography, vegetation type, and composition of soil community determine the ability of soils to sequester carbon, it is the microbial decomposers which ultimately regulate the rate-limiting steps in the decomposition process and thus the influence of abiotic factors on decomposition (Classen et al. $2015 \mathrm{a}, \mathrm{b})$. Warming brings about alterations in the physiology of decomposers, thereby influencing $\mathrm{CO}_{2}$ efflux from soil (Schindlbacher et al. 2011). Increasing temperatures are likely to accelerate fungal decomposition, resulting in increased carbon dioxide emission from soil. However, higher temperatures also elevate soil nitrogen levels that suppress the rates of fungal decomposition. In fact, greater nitrogen availability negatively affects microbial activity and diversity (American Society for Microbiology 2008). On the other hand, bacterial biochemical reactions under the stress exerted by warmer climate take place less efficiently. Hence, these microbes release more carbon as carbon dioxide instead of converting much of it into biomass (Zimmer 2010). The absorption of elevated levels of carbon dioxide produced in this way and other ways stimulates plants to emit nitrous oxide and methane (Center for Ecosystem Science and Society 2011). However, the overall microbial response to warming with respect to soil organic matter decomposition is dependent upon temperature sensitivity of the decomposers, substrate availability, interactions occurring with processes that take place above ground, and environmental variables such as soil moisture and potential physiological adaptations (Schindlbacher et al. 2011). It must be highlighted here that the effects of higher temperature on carbon dioxide release, due to decomposition, are unequal among different soils. In managed agricultural soils, microbial community suppressed the impacts of temperature change on carbon 
dioxide release. However, the greatest stimulation takes place in the soils of boreal and arctic ecosystems, which are warming most rapidly (University of Exeter 2014). Carbon use efficiency is a key determinant of the long-term stability of carbon in soil, because microbial biomass, rather than recalcitrant plant matter, is most resistant to decay (Conant et al. 2011; Schurig et al. 2013; Cotrufo et al. 2013).

\subsubsection{Effects of changes in precipitation}

Because of climate change, the risks of both drought and flooding (due to extreme precipitation) are increased as well as the timing of snowmelt is also shifted. Thus, the overall availability of water is affected (US EPA 2015d). This is quite significant as rainfall-induced fluxes are an important factor that determines whether ecosystems act as sources or sinks of $\mathrm{CO}_{2}$ for the atmosphere (Shim et al. 2009). In fact, rainfall is crucial in determining the variability of soil moisture and respiratory activity in soils (Aanderud et al. 2011). Shifts in precipitation regimes are quite significant because the level of moisture decides terrestrial microbial community structure and the extent of soil decomposition (affected by $20 \%$ increase or decrease in precipitation). The drying up of soils increases oxygen availability and stimulates carbon cycling in peatlands and wetlands, consequently elevating $\mathrm{CO}_{2}$ flux (Fierer and Schimel 2003; Singh et al. 2010). Among the numerous factors of climate change and their consequences that alter the overall abundance of bacteria and fungi, shifts in precipitation regimes have the most intense effects on community composition (Castro et al. 2010). Depending upon the factors which limit ecosystems productivity, modifications in precipitation and soil moisture levels could either increase or decrease the ratio of bacteria and fungi and trigger shifts in their community composition (Schimel et al. 1999; Williams 2007; Chen et al. 2007). In fact, minute changes in soil moisture $(<30 \%$ reduction in water-holding capacity) can change the dominance of species in soil fungal communities, although bacterial communities remain intact (Classen et al. 2015a, b).

Winter conditions affect the composition and activity of soil microbial communities and hence influence the sensitivity of soil respiration to moisture and temperature. Such conditions are therefore a variable for the flux of carbon dioxide $\left(\mathrm{CO}_{2}\right)$ from soils. The effects of snowfall on microbial communities and their metabolic activities can have a significant effect on winter soil respiration (Aanderud et al. 2013). In fact, snow-mediated changes in microbial community structure can profoundly affect wintertime respiration dynamics (Aanderud et al. 2013). Varied snowfall due to climate change has been predicted for several terrestrial ecosystems (IPCC 2007b; Henry
2008). This could have important consequences as the depth of snowpack is a significant determinant that controls winter soil respiration by exerting effects on temperature and moisture. Thick snowpacks insulate soils from colder air temperatures, which in turn can increase heterotrophic respiration (Mariko et al. 1994; Brooks et al. 1997; Rey et al. 2002). It must be mentioned here that microbial activity which occurs under snow in coniferous forests is vulnerable to temperature increase that occurs from climate change. In late winter, such activity is very high because of the extremely low temperature provided by snowpack, which is necessary for the development of snow molds. Such molds make a contribution of about $10-30 \%$ of the total annual carbon dioxide production in these areas. Increasing temperatures are likely to shorten the late winter period characterized by subfreezing temperatures. As a result, the snow molds would emit lesser amounts of carbon dioxide. However, this would have a negative impact in the form of increased mortality of trees, which depend on snow meltwater, which in turn would lead to an overall decrease in carbon fixation (American Society for Microbiology 2008).

\subsubsection{Effects of elevated carbon dioxide levels}

Elevated atmospheric levels of carbon dioxide cause soil microbes to emit more potent greenhouse gases such as methane and nitrous oxide (Pathak and Pathak 2012). In fact, higher $\mathrm{CO}_{2}$ levels not only increase $\mathrm{CH}_{4}$ efflux but also decrease the uptake of methane by soil microorganisms (up to $30 \%$ ) (Phillips et al. 2001; Ineson et al. 1998). Moreover, higher levels of carbon dioxide also lead to distinct and important alterations in the microbial communities of trees leaves and leaves that decompose in streams. This could have widespread consequences on the food chain as such microorganisms are a source of nutrients for the small phytophagous animals (American Society for Microbiology 2008). In addition, increase in microbial respiration takes place due to accelerated plant productivity that occurs due to elevated $\mathrm{CO}_{2}$ which in turn provides more carbon substrate to soil microorganisms (De Graaff et al. 2006).

\subsubsection{Effects mediated through plants}

Compared to aboveground vegetation, soils are shielded from the effects of climatic fluctuations (Durán et al. 2014). However, a number of indirect impacts of climate change propagate through the medium of plants to the associated soil communities (Kardol et al. 2010). In fact, the structure of belowground communities to a great extent depends upon the effect of environmental conditions acting on associated vegetation (Fierer and Jackson 2006). The 
indirect consequences of climate change arising from plant community shifts could not only be different from the direct effects but sometimes could have counteractive effects (Kardol et al. 2010). Alterations in rainfall can also have severe effects on plant-microbial relationship in soils (Yepez et al. 2007). Such linkages are important in determining the dynamics of soil respiration (Aanderud et al. 2011). It must be added that plants decrease the sensitivity of respiration under high rainfall variation but do the reverse under contradictory conditions in mesic habitats (Aanderud et al. 2011).

Plants exude carbon-rich liquids that are consumed by microbes. In the occurrence of stress, such as temperature, the type of such secretions changes, leading to alterations in the microbial secretions (Ngumbi 2015). Indirect impacts can also arise from the modification of soil pathogenic activities of plants which expand ranges under the influence of climate change (Engelkes et al. 2008; Morriën et al. 2011). Moreover, elevated induced production of defensive compounds such as polyphenols in such plants could influence litter input quality, which in turn alters the composition and activity of decomposer community (Engelkes et al. 2008). The phonologies of roots and shoots are altered due to climate change; consequently, interactions in the rhizosphere are altered that distinctly influences seasonal assemblages of soil microbes (Classen et al. 2015a, b). Plant functional traits are also altered due to modifications in microbial diversity (e.g., Lau and Lennon 2011). In fact, soil communities that remain in close association with plants migrating to higher altitudes under the influence of temperature rise are important factors that determine such transitions (Classen et al. 2015a, b). Higher soil temperatures also result in increased net plant productivity that provides more substrates for heterotrophs (Trumbore 1997). Similar effects also arise due to higher levels of $\mathrm{CO}_{2}$ which influence the release of labile sugars, amino acids, and organic acids from plant roots quantitatively and qualitatively. The dominance, diversity, growth, and activities of microbes are altered in accordance, which however also depends upon the availability of nutrients (such as nitrogen) and changes in $\mathrm{CO}_{2}$ flux (Diaz et al. 1993; De Graaff et al. 2006; Bardgett et al. 2009). In addition, soil microbial respiration physiology is also affected by plant feedback to $\mathrm{CO}_{2}$ (Singh et al. 2010).

Global warming is also likely to increase nutrient availability in soil due to greater mineralization of soil organic matter by microorganisms (Ruess et al. 1999). In addition, soil warming induces nitrogen mineralization, which increases plant productivity. Moreover, plant community composition often also changes with warming (Harte et al. 2006; Walker et al. 2006; Hoeppner and Dukes 2012). Increased temperature along with nutrient availability can lead to changes in vegetation (Havström et al. 1993; Hobbie 1996) which in turn affects microorganisms.

On the other hand, trees and shrubs which advance northward in the tundra under the influence of warmer temperatures can also influence microbes in unknown ways through the shadows which they cast on the ground (Zimmer 2010).

\subsection{Impacts on aquatic microbes}

\subsubsection{General effects}

There has been a rise of coastal water temperatures during the past century, and the warming is expected to occur by 4-8 ${ }^{\circ} \mathrm{F}$ in the twenty-first century (US EPA 2015b). A number of vital properties of water, which are crucial for ecosystems, are affected by changes in temperature. Hence, aquatic temperature fluctuations can potentially trigger dramatic changes in life-forms as well as even bring about their disappearance (NASA 2015b). In fact, environmental conditions that take place under influence of the greenhouse effect are expected to be favorable for specific species that have appropriate adaptations in the aquatic environment. This is precisely understood case of two groups of common oceanic nitrogen fixers, viz, Trichodesmium and Crocosphaera. Due to greenhouse conditions, elevated nitrogen-fixing productivity (up to $125 \%$ ) could occur in some strains of these groups, whereas the same could be inhibited in some others (Radford 2013).

Ocean warming has been resulting in profound changes. In addition, carbon dioxide accumulation has been leading to its acidification. Stratification of the ocean has also arisen because of the expansion of oxygen-depleted zones. Such changes are likely to have impacts on the microbial food webs and eventually biogeochemical cycles (Walsh 2015). As the polar ocean warms up, conditions in this ecosystem become more suitable for microbes. In fact, due to the warming of the polar oceans, marine microbes become more active and consequently more organic matter is consumed (Zimmer 2010). It is also a fact that as the temperature of ocean surface increases, its density decreases. Consequently, it tends to float over the nutrientrich cooler and deeper water. As a result, there is an inadequate supply of nutrients from below, and the phytoplanktons present in the upper layer are starved. Thus, primary production is suppressed, and pumping of carbon to the deeper water is decreased (Walsh 2015). An important determinant of the effect of temperature rise is the cell size. In the Arctic, smaller phytoplankton species continue to flourish but the larger undergo elimination under the effects of climate change. This is because in smaller cells, the surface-to-area ratio is higher, which 
makes them more efficient in nutrients acquirement. On the contrary, larger cells get sunk more quickly. Therefore, it is likely that phytoplankton cell size would decrease as global warming intensifies. Consequently, carbon pumped into the ocean interior would decrease due to the presence of smaller and more buoyant cells (Walsh 2015).

\subsubsection{Melting of ice}

The effects of global warming are evident in the case of Arctic sea ice, which reaches its minimum in September every year. The reduction in September Arctic sea ice has been occurring at a rate of $13.3 \%$ per decade, relative to the average of 1981-2010 (NASA 2015b). In Antarctica, the rate of loss of ice has been about $1.34 \times 10^{14} \mathrm{~kg}$ (134 billion metric tons) annually since 2002, whereas that in Greenland ice sheet, it is approximately $2.87 \times 10^{14} \mathrm{~kg}$ (287 billion metric tons) per year (NASA 2015b). Thus, because of global warming, the duration and extent of sea ice in the Arctic has been reduced. As a consequence, the abundance of ice algae which exist in the nutrient-rich ice is likely to be negatively affected. Such algae are consumed by zooplanktons, which are in turn are consumed by Arctic cod, an important food source for several marine mammals like seals. Seals are eaten by polar bears. Therefore, declines in ice algae that arise due to global warming can be a threat for polar bear populations (US EPA 2015c). Melting of ice due to temperature increase is also likely to cause salinity changes which affect water currents and stratification as well as cause dramatic shifts in the microbial community. In addition, melting of ice could release trapped organic matter and contaminants, which could affect microorganisms (Glöckner et al. 2012).

\subsubsection{Effects of storms arising due to climate change}

The occurrence of storms could also be affected by climate change. Such incidences in the Arctic flush nutrients from soils to oligotrophic lakes and streams, which can elevate nutrient supply to aquatic bacteria. Consequently, rapid fluctuations in temperature and greater availability of nutrients take place (under the influence of climate change). This may hamper the ability of bacterial communities to shift to an optimal activity for a given resource supply when environmental variability occurs simultaneously with their growth rate (Vadstein 2000; Stieglitz et al. 2003). These changes directly impact the growth and composition of bacterial communities (Judd et al. 2006). Certain aquatic ecosystems such as lakes and coastal areas in northern Europe are also likely to experience elevated inflow of nutrients and dissolved organic matter due to climate change, i.e., higher temperature and increased precipitation. This is likely to favor heterotrophy instead of autotrophy because phytoplankton growth would be restricted due to poor light conditions occurring because of higher concentrations of brown organic matter (Jones 1992; Klug 2002; Andreasson et al. 2004; Eriksson et al. 2010). Warmer temperatures and higher nutrient concentrations can also accelerate bacterial productivity and be selective for communities that reproduce fastest under those conditions (White et al. 1991; Ram and Sime Ngando 2008). This is because under conditions of nutrient availability, bacteria delays cell division in order to take advantage of the resources and increase in size (Shiomi and Margolin 2007).

\subsubsection{Effects of increased levels of carbon dioxide}

Global warming not only induces changes in the $\mathrm{pH}$ of seawater but also wind patterns, both of which have the potential to either hamper or stimulate microbial growth (Zimmer 2010). Increasing levels of carbon dioxide in the atmosphere are causing the oceans to absorb more of the gas and become more acidic. The consequent increase in acidity exerts significant impacts on coastal and marine ecosystems (US EPA 2015b). This decrease in pH in turn is likely to accelerate the dissolution of calcium carbonate, which would elevate dissolved $\mathrm{CO}_{2}$ and hence further decrease $\mathrm{pH}$, causing drastic effects of acidity (Glöckner et al. 2012). Enhanced carbon dioxide levels could also stimulate primary producers, causing phytoplankton blooms. Decomposition of the resulting organic matter could not only lead to oxygen depletion but also the genesis of toxic sulfide through anaerobic processes in marine environment (Glöckner et al. 2012). Carbon dioxide can also potentially control the biodiversity of keystone microbes of the ocean ecosystem (Radford 2013). An example is the bacterium Trichodesmium which is responsible for the conversion of nitrogen gas into consumable forms in nutrient-deficient portions of the ocean. The synthesized material is utilized by a number of other organisms. Increased levels of carbon dioxide could accelerate reproduction in the microbe, resulting in excessive consumption of this nutrient as well as iron and phosphorus that are not abundantly available in the ocean. The consequent deficiency would not only cause the extinction of the bacterium but also severely affect the whole marine food chain, including fishes (Howard 2015).

\subsubsection{A unique effect in oceans}

When phytoplanktons in the ocean are fed by bacteria, they break down into component molecules, such as fats and lipids. As the ocean surface churns, these become airborne to join aerosols. They eventually later develop into a framework where moisture droplets ultimately develop into 
clouds. The variations in specific ocean microbes, resulting from climate change, can affect the concentrations of less water-soluble molecules such as lipids in seawater and consequently the overall weather (Iacurci 2015). Climate change can also lead to the range extension of harmful microbes and in this way harm biodiversity. This fact can be exemplified by oyster parasite, Perkinsus marinus, which is capable of causing huge oyster deaths. The range of this parasite has expanded northward from Chesapeake Bay to Maine in the USA, i.e., a $498.90 \mathrm{~km}$ (310 mile) extension due to the increment of average winter temperatures (US EPA 2015c).

\subsubsection{Algal blooms}

Large freshwater bodies are likely to experience an increase in rise of $1-7{ }^{\circ} \mathrm{C}$ in surface temperature under a projected doubling of $\mathrm{CO}_{2}$ concentrations in the atmosphere (Magnuson et al. 1997). It must be noted also here that the warming of lakes has been taking place on an average by $0.61{ }^{\circ} \mathrm{F}\left(0.34{ }^{\circ} \mathrm{C}\right)$ every decade. In fact, lakes have also been losing their ice cover earlier in the spring in the northern climates. Moreover, lesser cover of cloud in several parts of the earth has increased the exposure of water bodies to solar radiation (NASA 2015b), leading to temperature rise. This rate of increase in lake temperatures is, however, higher at higher latitudes (NASA 2015b). Such warming rates, which are greater than those of the ocean and atmosphere, can have severe impacts on the microbial world (NASA 2015b). As a consequence, algal blooms, which lead to the depletion of water oxygen levels, are predicted to increase by $20 \%$ in lakes. Algal blooms which are toxic to fish and animals are projected to increase by $5 \%$ (NASA 2015b). In fact, there has been an increase in harmful algal blooms on the Pacific and Atlantic sides of North America during the last few decades due to warming (Mudie et al. 2002). Higher temperatures also favor the proliferation of cyanobacteria blooms directly through accelerated growth rates, and this is evident with regard to the development of the harmful cyanobacterium Microcystis during hot summers in eutrophic lakes (Jöhnk et al. 2008).

A similar phenomenon is also relevant in case of the marine environment, with respect to brown algae (Desmarestia spp.) in response to North Atlantic Oscillation Index (NAOI), which is a measure of the mean deviation from the average atmospheric sea-level pressure in the North Atlantic. Carpets of these algae have been found to appear in years of negative NAOI in the benthos due to increased nutrient supply. This represents a major congruence between the NAOI (which influences temperature and current regimes in the North Atlantic) as a large-scale driver of climate change and diversity in the benthos (Beuchel et al. 2006).

In addition, as levels of $\mathrm{CO}_{2}$ change during global warming, the ratio of carbon, nitrogen, and phosphorous in freshwater ecosystems is altered (Hasler et al. 2016). When the proportion of carbon exceeds that of nitrogen, phosphorous diminishes the nutritional quality of phytoplankton in nutrient-poor water bodies. Such consequences on the quality of phytoplankton hamper zooplankton growths, which in turn alters competitive advantages and community composition. These impacts can propagate up to higher levels of the food chain. In nutrient-rich water bodies, elevated levels of $\mathrm{CO}_{2}$ accelerate primary production as well as increase the abundance of nitrogen-fixing cyanobacteria (Hasler et al. 2016).

\section{Microbial feedbacks}

Soil microbes can either enhance (positive feedback) or reduce (negative feedback) the rate of climate change (Singh et al. 2010). According to Bardgett et al. (2008), climate change exerts direct and indirect impacts on soil microbial activities and evokes corresponding feedbacks accordingly. Direct effects occur due to temperature elevation or extreme conditions (e.g., drought and freezing). Indirect effects arise because of climate-induced changes in plant diversity and productivity and consequent changes. They used these effects as a scaffold to point out the role of soil microbes and their metabolism in carbon cycle feedbacks that lead to climate change. With this approach, they put forward two distinct carbon cycle feedback mechanisms that are present in the heterotrophic soil microbes (Fig. 3).

\subsection{Direct feedback}

\subsubsection{Temperature elevation}

Increased temperature enhances microbial respiration, leading to the mobilization of carbon from soil, and as per estimates, about $5 \%$ of total soil carbon would be lost within the next decade (Rustad et al. 2001; Davidson and Janssens 2006). It has been estimated that the magnitude is likely to range from 20 to $200 \mathrm{ppm}$ increase in atmospheric $\mathrm{CO}_{2}$ concentrations by 2100 (Friedlingstein et al. 2006). In other words, climate warming would increase the flow of carbon from the soil into the atmosphere and thus result in positive feedback on climate change (Cox et al. 2000; Friedlingstein et al. 2006). Climate warming could alter the decay dynamics of more stable organic matter and thus have a positive feedback to climate that suits more efficient microbial community in the longer term (Frey et al. 2013). 


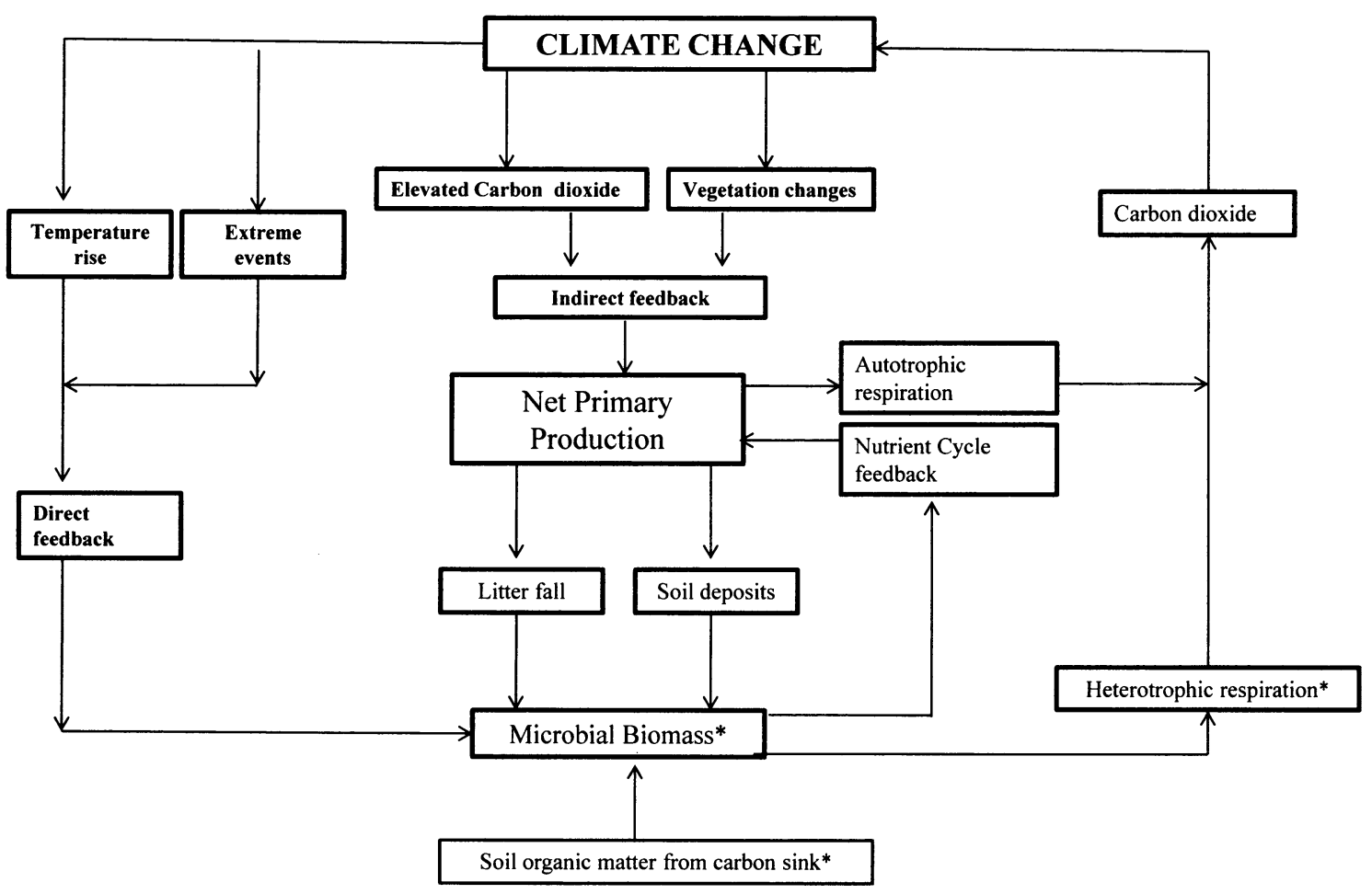

Fig. 3 Direct and indirect effects of climate change on the soil microbial communities and the associated routes of carbon cycle feedback to global warming through the production of carbon dioxide [asterisk components of the soil ecosystem (based on Bardgett et al. 2008)]

Another positive feedback (as mentioned earlier) exists with respect to world permafrost, $25 \%$ of which could thaw by 2100 . This would increase the availability of the protected organic matter for microbial decomposition, exerting positive feedback on carbon cycling (Anisimov et al. 1999). As per estimates, due to thawing, as high as $4 \times 10^{4} \mathrm{~kg}(400 \mathrm{Pg})$ of stored organic carbon in the permafrost will become vulnerable to enhanced decomposition rates (Zimov et al. 2006).

The change in the strength, structure, and diversity of the microbial community is also an important factor predicting feedback (Kandeler et al. 1998; Bardgett et al. 1999). For instance, temperature rise increases the relative abundance of Betaprotobacteria which favors respiration leading to positive feedback. This response is not ubiquitous to other types of bacteria (Frey et al. 2013). A number of such uncertainties exist, the cumulative effect of which has resulted in unsuccessful models that are unable to predict the soil carbon feedback mechanism based on the decomposition patterns (Kirschbaum 2004).

\subsubsection{Extreme events}

Stresses (e.g., drought and freezing) alter soil microbial activity (Schimel et al. 2007), but the consequences vary across different ecosystems (Bardgett et al. 2008).
Intensified drought conditions suppress microbial activity and create a negative feedback on microbial decomposition and soil carbon loss, and this can be correlated with the declining activity of the enzyme phenol oxidase that causes the decomposition of organic matter (Nardo et al. 2004). However, drought conditions in wetlands accelerate microbial activity by lowering the water table and introducing oxygen to anaerobic soil leading to positive carbon cycle feedback as reflected by the increased activity of phenol oxidases (Freeman et al. 2004; Zibilske and Bradford 2007). But it is accompanied by a decline in methane emission due to the toxic effects of oxygen and sensitivity of methanogens to desiccation (Bardgett et al. 2008; Fetzer et al. 1993).

However, as a whole, global warming is likely to increase $\mathrm{CH}_{4}$ emission (Zhuang et al. 2004). Increased net productivity under climate change enhances methane emission while reduced precipitation and soil drying have contradictory effects (Christensen et al. 2003).

\subsection{Indirect feedback}

Indirect microbial feedbacks are mediated through plant growth and composition of the vegetation of the ecosystem (Bardgett et al. 2008). Such feedbacks are operated basically via two different routes. 
1. The first mechanism of feedback is associated with the increase in atmospheric carbon dioxide which is a consequence of increased level of plant photosynthesis. This results in the transfer of photosynthate carbon from the plant body to the roots and associated mycorrhizal fungi (Johnson et al. 2005; Keel et al. 2006) and ultimately to heterotrophic soil bacteria (Zak et al. 1993; Bardgett et al. 2008) through root exudation of organic compounds leading to the increased carbon flow to the soil (Diaz et al. 1993; Zak et al. 1993). Due to this, the carbon availability for the soil microorganisms increases. This enhances soil respiration of microorganisms that releases carbon to the atmosphere. A portion of this carbon even gets dissolved in water and is mobilized (Zak et al. 1993; Freeman et al. 2004).

2. The second mechanism of climate change-driven microbial feedback requires some time to come into play as it is dependent upon the changes in the functional composition and diversity of vegetation of an ecosystem. Climate warming has been reported to bring changes in the distribution of plant species and functional groups. (Prentice et al. 1992; Woodward et al. 2004). Jackson et al. (1996) reported that such changes can alter the physical environment of the soil by modifying the root structure and depth. But this alteration in the vegetation structure brings about a significant modification in the quality and quantity of litter production which forms an important component of soil organic carbon (Bardgett et al. 2008). The variation in leaf litter determines the change in the plant functional groups (Aerts and Chapin 2000; Dorrepaal et al. 2005) which in turn is responsible for the rate of decomposition and heterotrophic soil respiration of the microbes. For instance, slow growing plants such as evergreen shrubs produce poor-quality litter which is rich in recalcitrant compounds like lignin and phenolic acid that do not undergo fast decomposition due to retarded microbial activity (Wardle 2002). A dominant presence of this kind of vegetation is likely going to produce negative feedback on carbon exchange and climate change, i.e., warming (Cornelissen et al. 2007). However, fast-growing plants such as legumes and graminoids produce highquality litter that undergo rapid microbial decomposition (Wardle 2002), and a dominant presence of this kind of vegetation will likely give rise to positive feedback on microbial activity and carbon mineralization leading to enhanced release of carbon dioxide to the atmosphere (Hanley et al. 2004; Ross et al. 2004).

In the end, considering the direct and indirect effects of climate change on the microbes and their various feedback mechanisms, it can be suggested that the carbon feedback cycle comprises of biological variables and climate variables (Singh et al. 2010). Their interactions in a simple diagrammatic way are presented in Fig. 4.

\section{Future prospect}

The average global surface air temperature has been projected to get elevated between 1.4 and $5.8^{\circ} \mathrm{C}$ by 2100 (World Meteorological Organization Web site), and predictions state that a surge of worldwide temperature by $2{ }^{\circ} \mathrm{C}$ would increase soil carbon release by $10^{6} \mathrm{~kg}(10$ petagrams) $\mathrm{CO}_{2}$ and other greenhouse gases (Raich and Potter 1995; Luo et al. 2001; Pendall et al. 2004). This would in turn lead to a vicious cycle of further temperature rise and environmental changes. With global warming, precipitation is expected to increase in northern middle and high latitudes and Antarctica during winter. Greater quantities of precipitation are likely to be released in few enormous outbursts instead of being distributed over numerous mild events (World Meteorological Organization Website).

Consequently, several environmental parameters of terrestrial and aquatic ecosystems are likely to change that would have profound impacts on microbes. A number of models exist that predict the impacts of such environmental changes on microbes (Dens and Van Impe 2001; Wilson et al. 2002). However, latest modeling techniques and investigations have revealed that long-term soil warming indicates a positive feedback between global warming and atmospheric release of soil organic matter, more than what was initially estimated (Kirschbaum 2004). The problem is expected to have a particularly strong impact in arctic terrestrial ecosystems. Hence, the Arctic has been highlighted as an important region for detecting global change (Ruess et al. 1999). However, there is a dearth of mechanistic models that predict the effect of climate change on soils (Liski et al. 2005).

Different ecosystems are likely to respond differently to the issue. For instance, it has been estimated that European forest soils would act as $\mathrm{CO}_{2}$ sinks in response to climate change, whereas agricultural soils would lose organic matter and therefore emit $\mathrm{CO}_{2}$ (Sleutel et al. 2003; Kirkby et al. 2005).

On the other hand, increased concentrations of atmospheric carbon dioxide are expected to increase its uptake by marine phytoplanktons up to $39 \%$. Although this can be expected to have a positive effect for the global climate system, decomposition of increased biomass would consume more oxygen, which is a major problem for deep ocean marine organisms. In addition, there could be an 


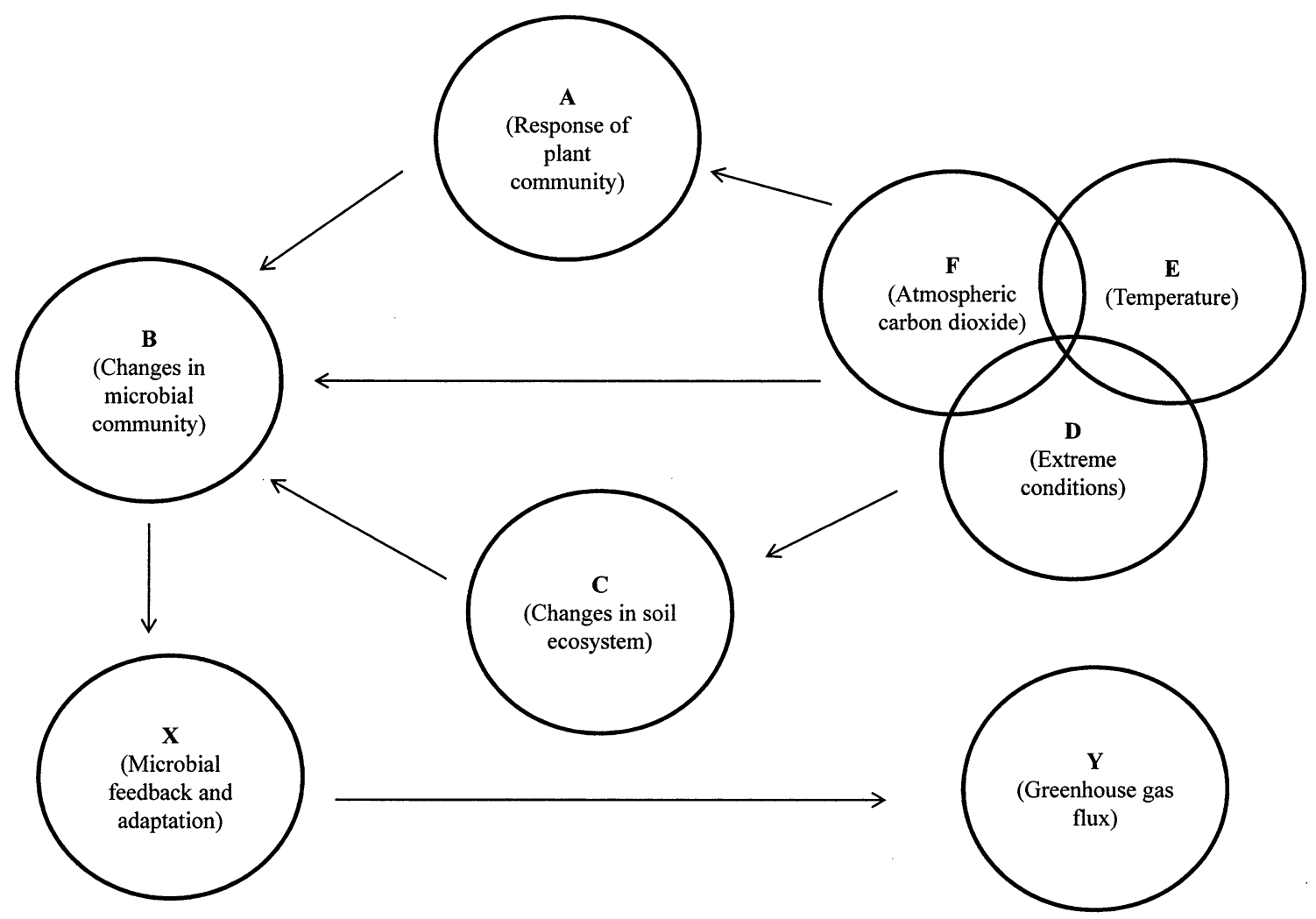

Fig. 4 Overall effect of climate change on microbes ( $A, B, C, X=$ Biological entities; $D, E, F, Y=$ Climatic entities)

accelerated rate of ocean acidification (Leibniz Institute of Marine Sciences 2007).

\section{Discussion}

Microorganisms are not only drivers of climate change but also respond to the phenomenon distinctly (Singh et al. 2010). However, although they are sensitive to global changes, their responses have not been understood (American Society for Microbiology 2008; Microbiology Online 2015). This is because microorganisms live in diverse communities which interact with other organisms and the environment in complex ways (Microbiology Online 2015).

\subsection{Significance of climate change}

Temperature plays a primary role in regulating the activity and growth in microorganisms (Rose 1967). The effects of temperature variation are manifested through variation in the uptake of various kinds of inorganic nitrogen and amino acids, enzymatic activity, coupling of cellular respiration to ATP production as well as response of cellular growth to respiration (Rose 1967; Crawford et al. 1974; Reay et al. 1999). In fact, both temperature and moisture are the most fundamental entities that affect the activities and existence of microorganisms. A host of other properties such as $\mathrm{pH}$ and conductivity in both soil and aquatic ecosystems are associated with these primary parameters. Climate change exerts its influence directly upon these primary variables, i.e., temperature and moisture, which in turn also alter all the associated variables. The resultant modifications are a composite effect of all changed variables and impose widespread impacts on the microbial world, most of which are negative. Several processes that are interrelated occur as consequence, and the complexity arises from the fact that all the impacts take place simultaneously.

The most distinct effect is exerted on respiration which is the primary vital activity to sustain life. All the other impacts follow one after another, and the effects later become visible at the community level and further above in the food webs in both terrestrial and aquatic environments. A directly related variable is the rate of decomposition, which has direct association with the release of greenhouse gases. It must be added that soil respiration contributes up to $10 \%$ of atmospheric emission of $\mathrm{CO}_{2}$. Elevated temperature accelerates emission of both $\mathrm{CO}_{2}$ and $\mathrm{CH}_{4}$ from soil by increasing the heterotrophic respiration. Soil contains two to three times more carbon than the atmosphere and terrestrial vegetation (Schlesinger 1977; Jobbagy and 
Jackson 2000), and the annual carbon dioxide $\left(\mathrm{CO}_{2}\right)$ flux due to soil respiration is about 10 times greater than that of fossil fuels (IPCC 2007a). Therefore, minute alterations in the rate of soil organic carbon decomposition can exert severe effects on the concentration of $\mathrm{CO}_{2}$ in the atmosphere. Temperature also directly exerts consequences on the growth rate and metabolism of marine microorganisms (Glöckner et al. 2012). In must be added that, as most of the earth is covered by water, the significance of water bodies (both fresh and marine) is of utmost importance.

\subsection{A comparative interpretation}

Microorganisms in aquatic and terrestrial environments contribute to the production as well as the removal of greenhouse gases. However, if both the two ecosystems are compared, it is found that each has a number of aspects unique to themselves. The issue of methane seeps is present only in oceans and exemplifies how microbes exert a controlling effect on climate change. Another remarkable aspect of the marine environment is the production of DMS (as mentioned earlier) which could be an important determinant of climate and its consequent effects on the microbial world. It in fact represents an interesting feedback mechanism relevant to microorganisms. In addition, there are algal blooms that represent an important negative impact of climate change present in the aquatic environment but absent from the terrestrial environment.

In case of the terrestrial ecosystem, the problem of permafrost is quite significant. It demonstrates a vicious cycle of negative impacts in which the microbial world acts as a catalyst and very well establishes them as drivers of climate change. In addition, there is greenhouse gas emission from agricultural lands, which is present only in case of the soil ecosystem and represents a combined impact of anthropogenic intervention and microbial effects. Plants are important determinants of the effects of consequences on soil microbes, whereas no such other entity is involved in case of aquatic ecosystem. This is evident from the fact that the accumulation and decomposition of litter in forests, which depend on climatic and biotic conditions, determine the availability of organic matter in soils as well as $\mathrm{pH}$. These in turn affect fluctuations of bacterial population and activity (Rigobelo and Nahas 2004). Now, as plants are distinctly affected by seasonal variations, the effects of seasons are likely to be more precise in terrestrial microbes. This in fact also provides a scope of research on plant species which can be effectively utilized to design soil microbial communities.

Thus, it is well understood that although the primary effect of climate change is roughly similar on all microbes, the intensity of resultant impacts and the pathway of occurrence differ between the two types of ecosystems. In fact, both have their own features which exert their effects. Some of the primary impacts such as changes in respiration and diversity are common. In all the cases, the main criterion is the temperature sensitivity of microbes.

\subsection{Need of proper study and suggestions}

Microbes have several positive and negative feedback responses to climate change (Microbiology Online 2015). This can be compared to the multiple feedbacks in benthic coral reef communities to global warming (Kubiceka and Reutera 2016). An example of a positive microbial feedback is the fact that global warming accelerates the decomposition of soil organic matter and thereby increases the carbon flux from soil to the atmosphere (Trumbore et al. 1996; Cox et al. 2000; IPCC 2007a). But microorganisms can also buffer the effects of increasing atmospheric carbon dioxide levels and thereby slow down climate change (Weiman 2015) and exert a controlling effect. A proper appreciation of the complex ecologies and response to climate change and other anthropogenic factors is immediately needed so that these microbial ecologies can be harnessed for climate change mitigation (Zimmerman and Labonte 2015).

Budzianowski (2012b) has suggested decreasing atmospheric $\mathrm{CO}_{2}$ emissions and/or removing atmospheric $\mathrm{CO}_{2}$ for the management of carbon. Microbes have the potential for both and hence could serve an instrument for combating climate change. On the other hand, NASA classifies approaches to prevent climate change into mitigation (reducing greenhouse gas emissions and stabilizing their levels) and adaptation (adapting to the climate change that is taking place) (NASA 2015a). For the former, all climate change parameters including microbes must be studied to be properly manipulated. Therefore, there is a need to understand the microbial response to warming by developing a clear appreciation of microbes, from the genetic and the physiological level up to composition and interactions (Pold and DeAngelis 2013). However, the irony is that microbes have not been adequately studied but also have been neglected with respect to this issue. For instance, most of the studies of climate change on soil microbes have concentrated around gross parameters, such as biomass, activity of enzymes, or basic community profiles in relation to single factors of climate (Castro et al. 2010). In this regard, it must be mentioned that microcalorimetry is an effective tool to study the effect of moisture on soil microbial activity (Barros et al. 1995).

The mechanism of action of the microbial carbon cycle feedback with respect to climate change is still enigmatic. Its proper understanding demands an in-depth research on all the direct and indirect effects of climate change on the heterotrophic soil microorganism and the corresponding 
feedback they evoke. In fact, a greater appreciation of the effects of global warming on carbon cycle feedbacks is a primary requirement to design models of future climate (Canadell et al. 2007). It must be noted here that the factor $\mathrm{Q}$ (i.e., the increase in microbial activity with a $10{ }^{\circ} \mathrm{C}$ increase in temperature) is mostly used in climate change models to represent microbial temperature sensitivity. The use of only Q may lead to unreliable predictions as it masks several interactions (e.g., decomposition) that influence microbial temperature sensitivity (Classen et al. 2015a, b).

New and better strategies must be developed into order to eradicate the prevailing uncertainty over the topic. The gravity of the situation demands to get rid of the provincial approaches and to adopt interdisciplinary methods which include proper amalgamation of elements from microbial taxonomy and ecology, metagenomics, soil and plant sciences, and ecological modeling. Molecular techniques like stable isotope probing (SIP) which involve the study of the functional genes important for biogeochemical processes, labeling of DNA, RNA, and phospholipid fatty acids (PLFA) of the microorganisms participating in the pathways involved in the feedbacks are promising approaches (Zak et al. 2006; Drigo et al. 2007). In this regard, the strategy put forward by Singh et al. (2010) seems to be worth applying. According to them, thorough research must be undertaken in order to quantify the microbial responses to the phenomenon of climate change. Parallel to this, proper screening, identification, and classification of the microbes must be done on the basis of functional and physiological roles in the field of greenhouse gas production and emission. The information gathered from this must be used to enhance the understanding of microbial control of greenhouse gas efflux to the atmosphere. In addition, aboveground and underground interactions along with the nutrient cycling must be studied. This is because plant interaction with soil communities, which is the most important controller of soil nitrogen and carbon dynamics, has also not been fully understood (Castro et al. 2010). However, it is a fact that climate change alters soil microbial communities and consequently the establishment and development of plant species. As a result, ecosystem responses are likely to change (Classen et al. 2015a, b).

Another important aspect is the issue of permafrost. In fact, reduction in methane emission from biomass fermentation and melting of permafrost have been identified to be crucially important for climate change mitigation (Budzianowski 2013).However, thawing of Arctic permafrost can be prevented if warming is limited to a global average of $2{ }^{\circ} \mathrm{C}$ (Atkin 2015). About 200 countries adopted a climate agreement at the COP21 summit in Paris which aims to control the planet's average global temperature rise within $2{ }^{\circ} \mathrm{C}$ (Shaftel 2015). Budzianowski (2012a, b) has suggested the development of advanced carbon sequestration concepts like sequestration of soil carbon and $\mathrm{CO}_{2}$ recycling to useful products such as fuels and fertilizers. On the other hand, in order to reduce nitrous oxide $\left(\mathrm{N}_{2} \mathrm{O}\right)$ emission to the atmosphere, the aim of management should be optimizing fertilizer $\mathrm{N}$ use efficiency instead of simply reducing application (Van Groenigen et al. 2011).

Taking into consideration all the above facts, it is well understood that the microbial aspect of climate change is a relevant issue of the present times. This fact needs to be properly studied and deserves to be given due importance. It should thus be appropriately incorporated in climate change models as any such model which fails to include microbial activities is inadequate (Dupré 2008). It is a matter of urgent requirement because current human activities have caused microbes to produce greater production of greenhouse gases (Microbiology Online 2015). In this regard, a few researchers have tried to incorporate microbial data (biomass, enzyme, and growth kinetics) into climate models (Lipson et al. 2009; Allison et al. 2010). However, for better predictions, information related to microbial diversity, community, their strength, and structure along with their physiological abilities must be taken into consideration (Singh et al. 2010).

\section{Conclusion}

The role of microorganisms in determining the atmospheric concentration of greenhouse gases is commendable, but it has yet to be properly understood and appreciated by the scientific community. Considering the observed uncertainties, it is apparent that the potential contributions of these microbes can be apprehended by considering the direct and indirect effects of climate change on them and their corresponding long-term and short-term responses. If harnessed properly, microbes could be an important natural resource for controlling climate change. However, if due attention is not given, it could act as the most emerging accelerator to the problem. It is high time to study this aspect, understand the acting mechanisms more precisely, and hence suitably utilize it for developing solutions.

\section{References}

Aanderud ZT, Schoolmaster DR Jr, Lennon JT (2011) Plants mediate the sensitivity of soil respiration to rainfall variability. Ecosystems 14:156-167

Aanderud ZT, Jones SE, Schoolmaster DR Jr, Fierer N, Lennon JT (2013) Sensitivity of soil respiration and microbial communities to altered snowfall. Soil Biol Biochem 57:217-227

Adams HE, Crump BC, Kling GW (2015) Isolating the effects of storm events on arctic aquatic bacteria: temperature, nutrients, and community composition as controls on bacterial productivity. Front Microbiol 6:250 
Aerts R, Chapin FS (2000) The mineral nutrition of wild plants revisited: a re-evaluation of processes and patterns. Adv Ecol Res 30:1-67

Allison SD, Vitousek PM (2005) Responses of extracellular enzymes to simple and complex nutrient inputs. Soil Biol Biochem 37:937-944

Allison SD, Wallenstein MD, Bradford MA (2010) Soil carbon response to warming dependent on microbial physiology. Nat Geosci 3:336-340

American Society for Microbiology (2008) Climate change could impact vital functions of microbes. Science Daily. www. sciencedaily.com/releases/2008/06/080603085922.htm. Accessed 15 Dec 2015

Anderson JPE, Domsch KH (2010) A physiological method for the quantitative measurement of microbial biomass in soil. Soil Biol Biochem 2010:215-221

Andreasson J, Bergstrom S, Carlsson B, Graham P, Lindstrom G (2004) Hydrological change: climate change impact simulations for Sweden. Ambio 33:228-234

Anisimov OA, Nelson FE, Pavlov AV (1999) Predictive scenarios of permafrost development under conditions of global climate change in the XXI century. Earth Cryol 3:15-25

Apple JK, del Giorgio PA, Kemp WM (2006) Temperature regulation of bacterial production, respiration, and growth efficiency in a temperate salt-marsh estuary. Aquatic Microbial Ecol 43:243-254

Atkin E (2015) Why this new study on arctic permafrost is so scary. http://thinkprogress.org/climate/2015/04/08/3643953/greenland permafrostthawmicrobes/. Accessed 15 Dec 2015

Avrahami S, Conrad R (2003) Patterns of community change among ammonia-oxidizers in meadow soils upon long-term incubation at different temperatures. Appl Environ Microbiol 69:6152-6164

Balser TC, McMahon KD, Bart D et al (2006) Bridging the gap between micro- and macro-scale perspectives on the role of microbial communities in global change ecology. Plant Soil 289:59-70

Bardgett RD, Kandeler E, Tscherko D, Hobbs PJ, Jones TH, Thompson LJ et al (1999) Below-ground microbial community development in a high temperature world. Oikos 85:193-203

Bardgett RD, Freeman C, Ostle NJ (2008) Microbial contributions to climate change through carbon cycle feedbacks. ISME J 2:805-814

Bardgett RD, De Deyn GB, Ostle NJ (2009) Plant-soil interactions and the carbon cycle. J Ecol 97:838-839

Barnard RX, Barthes L, LeRoux X et al (2004) Dynamics of nitrifying activities, denitrifying activities and nitrogen in grassland mesocosms as altered by elevated $\mathrm{CO}_{2}$. New Phytol 162:365-376

Barros N, Gomez Orellana I, Feijóo S, Balsa R (1995) The effect of soil moisture on soil microbial activity studied by microcalorimetry. Thermochim Acta 249(16):161-168

Beardall J, Raven JA (2004) The potential effects of global climate change on microalgal photosynthesis, growth and ecology. Phycologia 43(1):26-40

Beuchel F, Gulliksen B, Carrol ML (2006) Long-term patterns of rocky bottom macrobenthic community structure in an Arctic cord in relation to climate variability (1980-2003). J Mar Syst 63:35-48

Beveridge OS, Petchey OL, Humphries S (2010) Direct and indirect effects of temperature on the population dynamics and ecosystem functioning of aquatic microbial ecosystems. J Anim Ecol 79:1324-1331

Brooks PD, Schmidt SK, Williams MW (1997) Winter production of $\mathrm{CO}_{2}$ and $\mathrm{N}_{2} \mathrm{O}$ from Alpine tundra: environmental controls and relationship to inter-system $\mathrm{C}$ and $\mathrm{N}$ fluxes. Oecologia 110:403-413
Brose U, Williams RJ, Martinez ND (2006) Allometric scaling enhances stability in complex food webs. Ecol Lett 9:1228-1236

Brown JH, Gillooly JF, Allen AP, Savage VM, West GB (2004) Toward a metabolic theory of ecology. Ecology 85:1771-1789

Budzianowski WM (2012a) Negative carbon intensity of renewable energy technologies involving biomass or carbon dioxide as inputs. Renew Sustain Energy Rev 16(9):6507-6521

Budzianowski WM (2012b) Value-added carbon management technologies for low $\mathrm{CO}_{2}$ intensive carbon-based energy vectors. Energy 41(1):280-297

Budzianowski WM (2013) Tetrastable bifurcation structure of the climate system of Earth: mechanisms triggering potential transition to the greenhouse steady state. Int J Global Warming 5(2):152-178

Butterwick C, Heaney SI, Talling JF (2005) Diversity in the influence of temperature on the growth rates of freshwater algae, and its ecological relevance. Freshw Biol 50:291-300

Canadell JG, Quéré CL, Raupach MR, Field CB, Buitenhuis ET, Ciais P, Conway TJ, Gillett NP, Houghton RA, Marland G (2007) Contributions to accelerating atmospheric $\mathrm{CO}_{2}$ growth from economic activity, carbon intensity, and efficiency of natural sinks. Proc Natl Acad Sci USA 104:18866-18870

Cardon ZG, Gage DJ (2006) Resource exchange in the rhizosphere: molecular tools and the microbial perspective. Ann Rev Ecol Evol Syst 37:459-488

Castro HF, Classen AT, Austin EE, Norby RJ, Schadt CW (2010) Soil microbial community responses to multiple experimental climate change drivers. Appl Environ Microbiol 76(40):999-1007

Center for Climate and Energy Solutions, USA Website. http://www. c2es.org/factsfigures/mainghgs. Accessed 20 March 2016

Center for Ecosystem Science and Society (2011) Soil microbes accelerate global warming. https://nau.edu/ecoss/newsandevents/ pressreleases/soilmicrobes/. Accessed 15 Dec 2015

Chen MM, Zhu YG, Su YH, Chen BD, Fu BJ, Marschner P (2007) Effects of soil moisture and plant interactions on the soil microbial community structure. Eur J Soil Biol 43:31-38

Christensen TR et al (2003) Factors controlling large scale variations in methane emissions from wetlands. Geophys Res Lett 30:10-13

Classen AT, Sundqvist MK, Henning JA, Newman GS, Moore JAM, Cregger MA, Moorhead LC, Patterson CM (2015a) Direct and indirect effects of climate change on soil microbial and soil microbial plant interactions: What lies ahead? Ecosphere 6(8): $1-21$

Classen AT, Sundqvist MK, Henning JA, Newman GS, Moore JAM, Cregger MA, Moorhead LC, Patterson CM (2015b) Direct and indirect effects of climate change on soil microbial and soil microbial-plant interactions: What lies ahead? Ecosphere 6(8): 130

CMFRI (2009) Annual Report 200809. Central Marine Fisheries Research Institute, Cochin

Cole CV, Cerri C, Minami K et al (1996) Agricultural options for mitigation of greenhouse gas emissions. In: Watson RT, Zinyowera MC, Moss RH (eds) Climate change 1995 impacts, adaptations and mitigation of climate change: Scientific-technical analyses. Cambridge University Press, Cambridge, pp 745-771

Conant RT, Ryan MG, Ågren GI et al (2011) Temperature and soil organic matter decomposition rates-synthesis of current knowledge and a way forward. Global Change Biol 17:3392-3404

Conrad R (1996) Soil microorganisms as controllers of atmospheric trace gases $\left(\mathrm{H}_{2}, \mathrm{CO}, \mathrm{CH}_{4}, \mathrm{OCS}, \mathrm{N}_{2} \mathrm{O}\right.$ and $\left.\mathrm{NO}\right)$. Microbiol Rev 60:609-640

Cornelissen JHC, van Bodegom PM, Aerts R, Callaghan TV, van Logtestijn RSP, Alatalo J et al (2007) Global negative feedback 
to climate warming responses of leaf litter decomposition rates in cold biomes. Ecol Lett 10:619-627

Cotrufo MF, Wallenstein MD, Boot CM, Denef K, Paul E (2013) The microbial efficiency-matrix stabilization (MEMS) framework integrates plant litter decomposition with soil organic matter stabilization: Do labile plant inputs form stable soil organic matter? Glob Chang Biol 19:988-995

Cox PM, Betts RA, Jones CD, Spall SA, Totterdell IJ (2000) Acceleration of global warming due to carboncycle feedbacks in a coupled climate model. Nature 408:184-187

Crawford CC, Hobbie JE, Webb KL (1974) The utilization of dissolved free amino acids by estuarine microorganisms. Ecol 55:551-563

Crowther TW, Thomas SM, Maynard DS, Baldrian P, Covey K, Frey SD, van Diepen LTA, Bradford MA (2015) Biotic interactions mediate soil microbial feedbacks to climate change. Proc Natl Acad Sci 112(22):7033-7038

Davidson EA, Janssens IA (2006) Temperature sensitivity of soil carbon decomposition and feedbacks to climate change. Nature 440:165-173

Davidson E, Janssens I, Luo Y (2006) On the variability of respiration in terrestrial ecosystems: moving beyond $\mathrm{Q}(10)$. Global Change Biol 12:154-164

De Graaff MA, Van Groenigen KJ, Six J, Hungate B, van Kessel C (2006) Interactions between plant growth and soil nutrient cycling under elevated $\mathrm{CO}_{2}$ : a meta-analysis. Global Change Biol 12:2077-2091

Degerman R, Dinasquet J, Riemann L, de Luna SS, Andersson A (2013) Effect of resource availability on bacterial community responses to increased temperature. Aquatic Microbial Ecol 68:131-142

Dens EJ, Van Impe JF (2001) On the need for another type of predictive model in structured foods. Int $\mathrm{J}$ Food Microbiol 64:247-260

Diaz S, Grime JP, Harris J, Mcpherson E (1993) Evidence of a feedback mechanism limiting plant response to elevated carbon dioxide. Nature 364:616-617

DiGregorio BE (2015) Climate change affecting microbes in North America soils. American Society for Microbiology. https://www. microbemagazine.org/index.php?option=com_contentandview= articleandid=6497: climatechangeaffectingmicrobesinnorthameri casoils. Accessed 15 Dec 2015

Dorrepaal E, Cornelissen JHC, Aerts R, Wallen B, van Logtestijn RSP (2005) Are growth forms consistent predictors of leaf litter quality and decomposability across peatlands along a latitudinal gradient? J Ecol 93:817-828

Drigo B, Kowalchuk GA, Yergeau E, Bezemer TM, Boschker HTS, Van Veen JA (2007) Impact of elevated carbon dioxide on the rhizosphere communities of Carex arenaria and Festuca rubra. Global Change Biol 13:2396-2410

Dupré J (2008) Climate change and microbes: influence in numbers. http://environmentalresearchweb.org/cws/article/opinion/37020. Accessed 15 Dec 2015

Durán J, Morse JL, Groffman PM, Campbell JL, Christenson LM, Driscoll CT, Fahey TJ, Fisk MC, Mitchell MJ, Templer PH (2014) Winter climate change affects growing-season soil microbial biomass and activity in northern hardwood forests. Global Change Biol 20:3568-3577

Eliasson PE, McMurtrie RE, Pepper DA et al (2005) The response of heterotrophic $\mathrm{CO}_{2}$ flux to soil warming. Global Change Biol 11:167-181

Emmerson MC, Raffaelli D (2004) Predator-prey body size, interaction strength and the stability of a real food web. J Anim Ecol 73:399-409

Engelkes T, Morrien E, Verhoeven KJF, Bezemer TM, Biere A, Harvey JA, McIntyre LM, Tamis WLM, van der Putten WH
(2008) Successful range-expanding plants experience less aboveground and below-ground enemy impact. Nature 456:946-948

Eriksson H, Humborg C, Morth CM, Rodrigues Medina M, Wulff F (2010) Scenario analysis on protein consumption and climate change effects on riverine $\mathrm{N}$ export to the Baltic Sea. Environ Sci Technol 44:2379-2385

European Commission (2015) The role of Arctic microbes in climate change. CORDIS: News and Events. http://cordis.europa.eu/ news/rcn/127717_en.html. Accessed 15 Dec 2015

Falkowski PG, Fenchel T, Delong EF (2008) The microbial engines that drive earth's biogeochemical cycles. Science 320:1034-1039

Fetzer S, Bak F, Conrad R (1993) Sensitivity of methanogenic bacteria from paddy soil to oxygen and desiccation. FEMS Microbiol Ecol 12:107-115

Field CB, Behrenfeld MJ, Randerson JT, Falkowski P (1998) Primary production of the biosphere: integrating terrestrial and oceanic components. Science 281:237-240

Fierer N, Jackson RB (2006) The diversity and biogeography of soil bacterial communities. Proc Natl Acad Sci 103:626-631

Fierer N, Schimel JPA (2003) Proposed mechanism for the pulse in carbon dioxide production commonly observed following the rapid rewetting of a dry soil. Soil Sci Soc Am J 67:798-805

Fierer N, Craine JM, McLauchlan K et al (2005) Litter quality and the temperature sensitivity of decomposition. Ecology 86:320-326

Freeman C, Fenner N, Ostle NJ, Kang H, Dowrick DJ, Reynolds B et al (2004) Dissolved organic carbon export from peatlands under elevated carbon dioxide levels. Nature 430:195-198

French S, Levy-Booth D, Samarajeewa A, Shannon KE, Smith J, Trevors JT (2009) Elevated temperatures and carbon dioxide concentrations: effects on selected microbial activities in temperate agricultural soils. World J Microbiol Biotechnol 25:1887-1900

Frey SD, Lee J, Melillo JM, Johan Six J (2013) The temperature response of soil microbial efficiency and its feedback to climate. Nat Clim Change 3:395-398

Friedlingstein P, Bopp L, Rayner P et al (2006) Climate-carbon cycle feedback analysis: results from the C4MIP model intercomparison. J Clim 19:3337-3353

Glöckner FO, Stal LJ, Sandaa RA, Gasol JM, O'Gara F, Hernandez F, Labrenz M, Stoica E, Varela MM, Bordalo A, Pitta P (2012) Marine microbial diversity and its role in ecosystem functioning and environmental change. In: Calewaert JB, McDonough N (eds) Marine Board Position Paper 17. Marine Board-ESF, Ostend, Belgium, pp 13-25

Gruber N, Keeling CD, Bates NR (2002) Interannual variability in the North Atlantic Ocean carbon sink. Science 298:2374-2378

Guntiñas ME, Gil-Sotres F, Leirós MC, Trasar-Cepeda C (2013) Sensitivity of soil respiration to moisture and temperature. J Soil Sci Plant Nutri 13(2):445-461

Hanley ME, Trofmov S, Taylor G (2004) Species-level effects more important than functional group-level responses to elevated $\mathrm{CO}_{2}$ : evidence from simulated turves. Funct Ecol 18:304-313

Harte J, Saleska S, Shih T (2006) Shifts in plant dominance control carbon-cycle responses to experimental warming and widespread drought. Environ Res Lett 1:014001

Hasler CT, Butman D, Jeffrey JD, Suski CD (2016) Freshwater biota and rising $\mathrm{p}^{\mathrm{CO} 2}$ ? Ecol Lett 19:98-108

Havström M, Callaghan TV, Jonasson S (1993) Differential growth responses of Cassiope tetragona, an arctic dwarf-shrub, to environmental perturbations among three contrasting high and subarctic sites. Oikos 66:389-402

Henry HAL (2008) Climate change and soil freezing dynamics: historical trends and projected changes. Climatic Change $87: 421-434$ 
Hibbard K, Law B, Reichstein M, Sulzman J (2005) An analysis of soil respiration acrossnorthern hemisphere temperate ecosystems. Biogeochemistry 73:29-70

Hiscock K, Southward A, Tiley AJ, Hawkins S (2001) The impact of climate change on subtidal and intertidal benthic species in Scotland. Scottish Natural Heritage, Research, Survey and Monitoring Report

Hobbie SE (1996) Temperature and plant species control over litter decomposition in Alaskan tundra. Ecol Mongr 66:503-522

Hoeppner SS, Dukes JS (2012) Interactive responses of old-field plant growth and composition to warming and precipitation. Global Change Biol 18:1754-1768

Hoppe HG, Breithaupt P, Walther K, Koppe R, Bleck S, Sommer U, Jurgens K (2008) Climate warming in winter affects the coupling between phytoplankton and bacteria during the spring bloom: a mesocosm study. Aquatic Microbial Ecol 51:105-115

Howard E (2015) http://www.theguardian.com/environment/2015/ sep/02/climatechangewillalteroceanmicroorganismscrucialtofood chainsayscientists. Accessed 15 Dec 2015

Huertas IE, Rouco M, López-Rodas V, Costas E (2011) Warming will affect phytoplankton differently: evidence through a mechanistic approach. Proc R Soc B. doi:10.1098/rspb.2011.0160

Iacurci J (2015) Ocean microbes: how they may directly impact climate change. http://www.natureworldnews.com/articles/ 14761/20150519/oceanmicrobeshowtheymaydirectlyimpactclimate change.htm. Accessed 15 Dec 2015

Ineson P, Coward PA, Hartwig UA (1998) Soil gas fluxes of $\mathrm{N}_{2} \mathrm{O}$, $\mathrm{CH}_{4}$ and $\mathrm{CO}_{2}$ beneath Lolium perenne under elevated $\mathrm{CO}_{2}$ : the Swiss free air carbon dioxide enrichment experiment. Plant Soil 198:89-95

IPCC (2007a) Climate change 2007: the physical science basis. Cambridge University Press, Cambridge

IPCC (2007b) Climate Change 2007: the scientific basis. Cambridge Press, Cambridge

Irish Marine Life website. Algae as indicators of climate change. https://irishmarinelife.wordpress.com/algaeasindicatorsofclimate change/. Accessed 4 March 2016

Jackson RB, Canadell J, Ehleringer JR, Mooney HA, Sala OE, Schulze ED (1996) A global analysis of root distributions for terrestrial biomes. Oecologia 108:389-411

Joa J, Moon K, Chun S, Kyung-San Choi, Hae-Nam Hyun H (2010) Effect of temperature on soil microbial biomass, enzyme activities and PLFA content during incubation period of soil treated with organic materials. In: Proceedings of 19th world congress of soil science, soil solutions for a changing world 1-6 August 2010, Brisbane, Australia. Published on DVD

Jobbagy EG, Jackson RB (2000) The vertical distribution of soil organic carbon and its relation to climate and vegetation. Ecol Appl 10:423-436

Joergensen RG (2010) Organic matter and micro-organisms in tropical soils. In: Dion P (ed) Soil biology and agriculture in the tropics. Springer, Berlin, pp 17-43

Jöhnk KD, Huisman J, Sharples J, Sommeijer B, Visser PM, Stroom JM (2008) Summer heat waves promote blooms of harmful cyanobacteria. Global Change Biol 14:495-512

Johnson D, Kresk M, Stott AW, Cole L, Bardgett RD, Read DJ et al (2005) Soil invertebrates disrupt carbon flow through fungal networks. Science 309:1047

Jones RI (1992) The influence of humic substances on lacustrine planktonic food chains. Hydrobiologia 229:73-91

Judd KE, Crump BC, Kling GW (2006) Environmental drivers control ecosystem function in bacteria through changes in community composition. Ecology 87:2068-2079

Kandeler E, Tscherko D, Bardgett RD, Hobbs PJ, Kampichler C, Jones TH (1998) The response of soil microorganisms and roots to elevated $\mathrm{CO}_{2}$ and temperature in a terrestrial model ecosystem. Plant Soil 202:251-262

Kardol P, Cregger MA, Campany CE, Classen AT (2010) Soil ecosystem functioning under climate change: plant species and community effects. Ecol 91:767-781

Keel SG, Siegwolf RTW, Körner C (2006) Canopy $\mathrm{CO}_{2}$ enrichment permits tracing the fate of recently assimilated carbon in a mature deciduous forest. New Phytol 172:319-329

Kirkby KJ, Smart SM, Black HIJ, Bunce RGH, Corney PM, Smithers RJ (2005) Long term ecological change in British woodland (1971-2001). English Nature Research Report 653, English Nature, Peterborough

Kirschbaum MUF (2004) Soil respiration under prolonged soil warming: are rate reductions caused by acclimation of substrate loss? Global Change Biol 10:1870-1877

Klug JL (2002) Positive and negative effects of allochthonous dissolved organic matter and inorganic nutrients on phytoplankton growth. Can J Fish Aquatic Sci 59:85-95

Kubiceka A, Reutera H (2016) Mechanics of multiple feedbacks in benthic coral reef communities. Ecol Model 329:29-40

Larionova A, Yevdokimov IV, Bykhovets SS (2007) Temperature response of soil respiration is dependent on concentration of readily decomposable C. Biogeosciences 4:1073-1081

Lau JA, Lennon JT (2011) Evolutionary ecology of plant-microbe interactions: soil microbial structure alters selection on plant traits. New Phytol 192:215-224

Lauenroth WK, Bradford JB (2006) Ecohydrology and the partitioning AET between transpiration and evaporation in a semiarid steppe. Ecosystems 9:756-767

Leibniz Institute of Marine Sciences (2007) Ocean plankton reducing greenhouse gases by using more carbon dioxide. https://www. sciencedaily.com/releases/2007/11/071117121016.htm. Accessed 20 March 2016

Lipson DA, Monson RK, Schmidt SK, Weintraub MN (2009) The trade-off between growth rate and yield in microbial communities and the consequences for under-snow soil respiration in a high elevation coniferous forest. Bigeochemistry 95:23-35

Liski J, Palosuo T, Peltoniemi M, Sievänen R (2005) Carbon and decomposition model Yasso for forest soils. Ecol Model 189:168-182

Luo Y, Zhou X (2006) Soil respiration and the environment. Academic Press, London

Luo Y, Wan S, Hui D et al (2001) Acclimation of soil respiration to warming in a tall grass prairie. Nature 413:622-625

Magnuson JJ, Webster KE, Assel RA, Bowser CJ, Dillon PJ (1997) Potential effects of climate changes on aquatic systems: Laurentian great lakes and Precambrian shield region. Hydrol Process 11:825-871

Mariko S, Bekku Y, Koizumi H (1994) Effux of carbon dioxide from snow-covered forest floors. Ecol Res 9:343-350

McCormick PV, Cairns J (1994) Algae as indicators of climate change. J Appl Phycol 6(5-6):509-526

Meehl GA et al (2007) In: Solomon S, Qin D, Chen MZ, Marquis M, Averyt KB, Tignor M, Miller HH (eds) Climate change 2007: the physical science basis. Contribution of Working Group I to the Fourth Assessment Report of the Intergovernmental Panel on Climate Change. Cambridge University Press, Cambridge, pp 748-845

Melillo JM, Steudler PA, Aber JD, Newkirk KM, Lux H, Bowles FP, Catricala C, Magill AH, Ahrens T, Morrisseau S (2002) Soil warming and carbon-cycle feedbacks to the climate system. Science 298:2173-2176

Melillo JM, Butler S, Johnson J et al (2011) Soil warming, carbonnitrogen interactions, and forest carbon budgets. Proc Natl Acad Sci USA 108:9508-9512 
Microbiology Online (2015) Microbes and climate change. http:// www.microbiologyonline.org.uk/aboutmicrobiology/microbe sandclimatechange. Accessed 15 Dec 2015

Morita RY (1974) Temperature effects on marine microorganisms. In: Colwell RR, Morita RY (eds) Effect of the ocean environment on microbial activities. University Park Press, Baltimore, pp 75-79

Morriën E, Engelkes T, van der Putten WH (2011) Additive effects of aboveground polyphagous herbivores and soil feedback in native and range-expanding exotic plants. Ecology 92:1344-1352

Mudie PJ, Rochon A, Levac E (2002) Palynological records of red tide-producing species in Canada: past trends and implications for the future. Paleogeogr Paleoclimatol Paleoecol 180:159-186

Nardo CD, Cinquegrana A, Papa S, Fuggi A, Fioretto A (2004) Laccase and peroxidase isoenzymes during leaf litter decomposition of Quercus ilex in a Mediterranean ecosystem. Soil Biol Biochem 36:1539-1544

NASA (2015a) http://climate.nasa.gov/solutions/adaptation-mitiga tion/. Accessed 15 Dec 2015

NASA (2015b) http://climate.nasa.gov/. Accessed 15 Dec 2015

Nedwell DB (1999) Effect of low temperature on microbial growth: lowered affinity for substrates limits growth at low temperature. FEMS Microbiol Ecol 30:101-111

Ngumbi E (2015) Turning to bacteria to fight the effects of climate change. http://blogs.scientificamerican.com/guestblog/turningto bacteriatofighttheeffectsofclimatechange/. Accessed 15 December 2015

Pathak A, Pathak R (2012) Microorganisms and global warming. Int J Appl Microbiol Sci 1:21-23

Pendall E, Bridgham S, Hanson PJ, Hungate B, Kicklighter DW, Johnson DW, Law BE, Luo Y, Megonigal JP, Olsrud M, Ryan MG, Shiqiang W (2004) Below-ground process responses to elevated $\mathrm{CO}_{2}$ and temperature: a discussion of observations, measurement methods and models. New Phytol 162:311-322

Phillips RL, Whalen SC, Schlesinger WH (2001) Influence of atmospheric $\mathrm{CO}_{2}$ enrichment on methane consumption in a temperate forest soil. Global Change Biol 7:557-563

Piotrowski J (2015) Microbes play villainous role in Arctic climate change. https://www.newscientist.com/article/dn27420microbes playvillainousroleinarcticclimatechange/. Accessed 15 Dec 2015

Pold G, DeAngelis KM (2013) Up against the wall: the effects of climate warming on soil microbial diversity and the potential for feedbacks to the carbon cycle. Diversity 5:409-425

Prentice IC, Cramer W, Harisson SP, Leemans R, Monserud RA, Solomon AM (1992) A global biome model based on plant physiology and dominance, soil properties and climate. J Biogeogr 19:117-134

Radford T (2013) Ocean microbes feel a warming climate's effects. http://www.climatecentral.org/news/oceanmicrobesfeelawarming climateseffects16237. Accessed 15 Dec 2015

Raich JW, Potter CS (1995) Global patterns of carbon dioxide emission from soils. Global Biogeochem Cycles 9:23-36

Raich J, Schlesinger W (1992) The global carbon-dioxide flux in soil respiration and itsrelationship to vegetation and climate. Tellus B 44:81-99

Ram ASP, Sime Ngando T (2008) Functional responses of prokaryotes and viruses to grazer effects and nutrient additions in freshwater microcosms. ISME J 2:498-509

Reay DS, Nedwell DB, Priddle J, Ellis-Evans JC (1999) Temperature dependence of inorganic nitrogen uptake: reduced affinity for nitrate at suboptimal temperatures in both algae and bacteria. Appl Environ Microbiol 65:2577-2584

Rey A, Jarvis P (2006) Modelling the effect of temperature on carbon mineralization rates across a network of European forest sites (FORCAST). Global Change Biol 12:1894-1908
Rey A, Pegoraro E, Tedeschi V, De Parri I, Jarvis PG, Valentini R (2002) Annual variation in soil respiration and its components in a coppice oak forest in Central Italy. Global Change Biol 8:851-866

Rigobelo EC, Nahas E (2004) Seasonal fluctuations of bacterial population and microbial activity in soils cultivated with eucalyptus and pinus. Sci Agri (Piracicaba, Brazil) 61(1) http:// www.scielo.br/scielo.php?script=sci_arttext\&pid=S0103901620 04000100015. Accessed 20 March 2016

Robertson GP, Paul EA, Harwood RR (2000) Greenhouse gases in intensive agriculture: contributions of individual gases to the radiative forcing of the atmosphere. Science 289:1922-1925

Rodrigo A, Recous S, Neel C, Mary B (1997) Modelling temperature and moisture effects on $\mathrm{C}-\mathrm{N}$ transformations in soils: comparison of nine models. Ecol Model 102:325-339

Rose AH (1967) Thermobiology. Academic Press, London

Ross DJ, Newton PCD, Tate KR (2004) Elevated $\mathrm{CO}_{2}$ effects on herbage and soil carbon and nitrogen pools and mineralization in a species-rich, grazed pasture on a seasonally dry sand. Plant Soil 260:183-196

Ruess L, Michelsen A, Schmidt IK, Jonasson S (1999) Simulated climate change affecting microorganisms, nematode density and biodiversity in subarctic soils. Plant Soil 212:63-73

Rustad L, Campbell J, Marion G et al (2001) A meta-analysis of the response of soil respiration, net nitrogen mineralization, and aboveground plant growth to experimental ecosystem warming. Oecology 126:543-562

Sarmento H, Montoya JM, Domínguez EV, Vaqué D, Josep M, Gasol JM (2010) Warming effects on marine microbial food web processes: how far can we go when it comes to predictions? Philos Trans R Soc B. doi:10.1098/rstb.2010.0045

Sarmiento JL, Gruber N (2002) Sinks for anthropogenic carbon. Phys Today 55:30-36

Savage K, Davidson E, Richardson A, Hollinger D (2009) Three scales of temporal resolutionfrom automated soil respiration measurements. Agric For Meteorol 149:2012-2021

Schimel JP, Gulledge JM, Clein-Curley JS, Lindstrom JE, Braddock JF (1999) Moisture effects on microbial activity and community structure in decomposing birch litter in the Alaskan taiga. Soil Biol Biochem 31:831-838

Schimel J, Balser TC, Wallenstein M (2007) Microbial stressresponse physiology and its implications for ecosystem function. Ecology 88:1386-1394

Schindlbacher A, Rodler A, Kuffner M, Kitzler B, Sessitsch A, Zechmeister Boltenstern S (2011) Experimental warming effects on the microbial community of a temperate mountain forest soil. Soil Biol Biochem 43(7):1417-1425

Schlesinger WH (1977) Carbon balance in terrestrial tetritus. Ann Rev Ecol Sys 8:51-81

Schlesinger WH (1997) Biogeochemistry, an analysis of global change. Academic Press, San Diego

Schlesinger WH, Andrews JA (2000) Soil respiration and the global carbon cycle. Biogeochem 48:7-20

Schurig C, Smittenberg RH, Berger J, Kraft F, Woche S, Goebel MO, Heipieper HJ, Miltner A, Kaestner M (2013) Microbial cellenvelope fragments and the formation of soil organic matter: a case study from a glacier forefield. Biogeochemistry 113:595-612

Scott-Denton LE, Rosenstiel TN, Monson RK (2006) Differential controls by climate and substrate over the heterotrophic and rhizospheric components of soil respiration. Global Change Biol 12:205-216

Shade A, Peter H, Allison SD et al (2012) Fundamentals of microbial community resistance and resilience. Front Aquatic Microbiol $3: 417$ 
Shaftel H (2015) Historic climate agreement adopted at COP21 summit in Paris. NASA's Jet Propulsion Laboratory. http:// climate.nasa.gov/news/2373/. Accessed 15 Dec 2015

Shim JH, Pendall E, Morgan JA, Ojima DS (2009) Wetting and drying cycles drive variations in the stable carbon isotope ratio of respired carbon dioxide in semi-arid grassland. Oecology 160:321-333

Shiomi D, Margolin W (2007) A sweet sensor for sizeconscious bacteria. Cell 130:216-218

Sieburth J (1967) Seasonal selection of estuarine bacteria by water temperature. J Exp Marine Biol Ecol 1:98-121

Simon M, Wünsch C (1998) Temperature control of bacterioplankton growth in a temperate large lake. Aquatic Microbial Ecol 16:119-130

Singh BK, Bardgett RD, Smith P, Reay DS (2010) Microorganisms and climate change: terrestrial feedbacks and mitigation options. Nat Rev Microbiol 8:779-790

Sleutel S, De Neve S, Hofman G (2003) Estimates of carbon stock changes in Belgian cropland. Soil Use Manag 19: 166-171

Smith P, Fang C, Dawson JJC, Moncrieff JB (2008) Impact of global warming on soil organic carbon. Adv Agron 97:1-43

Sniegowski PD, Lenski RE (1995) Mutation and adaptation: the directed mutation controversy in evolutionary perspective. Annu Rev Ecol Evol Syst 26:553-578

Sommer U, Lengfellner K (2008) Climate change and the timing, magnitude, and composition of the phytoplankton spring bloom. Global Change Biol 14:1199-1208

Stark JM, Firestone MK (1995) Mechanisms for soil moisture effects on activity of nitrifying bacteria. Appl Environ Microbiol 61(1):218-221

Staroscik AM, Smith DC (2004) Seasonal patterns in bacterioplankton abundance andproduction in Narragansett Bay, Rhode Island, USA. Aquatic Microbial Ecol 35:275-282

Stewart R (2003) Oceanography in the 21st century. Presentation given at the National Marine Educators Association Annual Meeting, Wilmington in North Carolina in July 2003. http:// oceanworld.tamu.edu/NMEA_Talk/NMEA_Talk_2003.html. Accessed 15 Dec 2015

Stieglitz M, Shaman J, McNamara J, Engel V, Shanley J, Kling GW (2003) An approach to understanding hydrologic connectivity on the hillslope and the implications for nutrient transport. Glob Biogeochem Cycles 17:1105

Stone MM, Weiss MS, Goodale CL, Adams MB, Fernandez IJ, German DP et al (2012) Temperature sensitivity of soil enzyme kinetic sunder $\mathrm{N}$-fertilization in two temperate forests. Global Change Biol 18:1173-1184

Suttle CA (2007) Marine viruses- major players in the global ecosystem. Nat Rev Microbiol 5:801-812

Suzuki Y, Takahashi M (1995) Growth responses of several diatoms isolated from various environments to temperature. J Phycol $31: 880-888$

Svoboda E (2015a) Below our feet, a world of hidden life. https:// www.quantamagazine.org/20150616soilmicrobesbacteriaclimate change/. Accessed 15 Dec 2015

Svoboda E (2015b) How wetland microbes impact global climate http://discovermagazine.com/2015/june/22smallwonders. Accessed 15 Dec 2015

The Core Writing Team (2007) Climate change 2007: Synthesis Report Contribution of Working Groups I, II and III to the Fourth Assessment. Report of the Intergovernmental Panel on Climate Change. IPCC, Geneva, Sweden

The USGS Water Science School (2015) http://water.usgs.gov/edu/ temperature.html. Accessed 20 March 2016

Tilman D, Fargione J, Wolff B et al (2001) Forecasting agriculturally driven global environmental change. Science 292:281-284
Trasar-Cepeda C, Gil-Sotres F, Leiros MC (2007) Thermodynamic parameters of enzymes in grassland soils from Galicia, NW Spain. Soil Biol Biochem 39:311-319

Trinastic J (2015) Methane-munching microbes limit global warming. http://www.nature.com/scitable/blog/eyesonenvironment/metha nemunching_microbes_limit_global_warming. Accessed 15 Dec 2015

Trumbore SE (1997) Potential responses of soil organic carbon to global environmental change. Proc Natl Acad Sci 94:8284-8291

Trumbore SE, Chadwick OA, Amundson R (1996) Rapid exchange between soil carbon and atmospheric carbon dioxide driven by temperature change. Science 272:393-396

Union of Concerned Scientists. (2011) http://www.climatehotmap. org/globalwarmingeffects/lakesandrivers.Html. Accessed 20 March 2016

University of Arizona (2014) Recently discovered microbe is key player in climate change. http://www.eurekalert.org/pub_ releases/201410/uoardm102014.php. Accessed 15 Dec 2015

University of Exeter 2014 Carbon stored in world's soils more vulnerable to climate change than expected."ScienceDaily. ScienceDaily, 3 Sept 2014. https://www.sciencedaily.com/ releases/2014/09/140903133313.htm. Accessed 4 May 2016

US EPA (2015a) Climate change: basic information. http://www3. epa.gov/climatechange/basics/. Accessed 15 Dec 2015

US EPA (2015b) http://www3.epa.gov/climatechange/impacts/coasts. html. Accessed 15 Dec 2015

US EPA (2015c) http://www3.epa.gov/climatechange/impacts/ecosys tems.html. Accessed 15 Dec 2015

US EPA (2015d) http://www3.epa.gov/climatechange/impacts/for ests.html. Accessed 15 Dec 2015

US EPA (2016) Climate change: Greenhouse Gas Emissions: Greenhouse Gases Overview https://www3.epa.gov/climate change/ghgemissions/gases.html 2016. Accessed 20 March 2016

Vadstein O (2000) Heterotrophic, planktonic bacteria and cycling of phosphorus requirements, competitive ability, and food web interactions. In: Schink B (ed) Advances in microbial ecology, vol 16. Kluwer Academic/Plenum Publisher, New York, pp 115-167

Van Groenigen JW, Oenema O, Van Groenigen KJ, Velthof G, Van Kessel C (2011) Best nitrogen management practices to decrease greenhouse gas emissions. Better Crops 95(2):16-17

Vivekanandan E (2016) Role of marine microorganisms in climate change. http://www.envismadrasuniv.org/nl20134Roleofmarine microorganismsinclimatechange.htm. Accessed 20 March 2016

Walker MD, Wahren CH, Hollister RD et al (2006) Plant community responses to experimental warming across the tundra biome. Proc Natl Acad Sci USA 103:1342-1346

Wallenstein MD, McMahon SK, Schimel JP (2009) Seasonal variation in enzyme activities and temperature sensitivities in Arctic tundra soils. Global Change Biol 15:1631-1639

Wallenstein MD, Haddix ML, Lee DD, Conant RT, Paul EA (2012) A litter-slurry technique elucidates the key role of enzyme production and microbial dynamics in temperature sensitivity of organic matter decomposition. Soil Biol Biochem 47:18-26

Walsh DA (2015) Consequences of climate change on microbial life in the ocean. Microbiol Today (Nov 2015 issue). Microbiology Society, England

Wang G, Post WM (2012) A theoretical reassessment of microbial maintenance and implications for microbial ecology modeling. FEMS Microbiol Ecol 81:610-617

Wang G, Post WM, Mayes MA (2013) Development of microbialenzyme-mediated decomposition model parameters through steady-state and dynamic analyses. Ecol Appl 23:255-272

Wardle DA (2002) Communities and ecosystems: linking the aboveground and belowground components. Princeton University Press, Princeton 
Weiman S (2015) Microbes help to drive global carbon cycling and climate change. Microb Mag 10(6):233-238

White PA, Kalff J, Rasmussen JB, Gasol JM (1991) The effect of temperature and algal biomass on bacterial production and specific growth rate in freshwater and marine habitats. Microbial Ecol 21:99-118

Williams MA (2007) Response of microbial communities to water stress in irrigated and drought-prone tall grass prairie soils. Soil Biol Biochem 39:2750-2757

Wilson PDG, Brocklehurst TF, Arino S, Thuault D, Jakobsen M, Lange M, Farkas J, Wimpenny JWT, Van Impe JF (2002) Modelling microbial growth in structured foods: towards a unified approach. Int J Food Microbiol 73:275-289

Woodward FI, Lomas MR, Kelly CK (2004) Global climate and the distribution of plant biomes. Proc R Soc Lond Ser B Biol Sci 359:1465-1476

World Meteorological Organization Website https://www.wmo.int/ pages/themes/climate/elements_climate_change.php. Accessed 20 March 2016

Wu Z, Dijkstra P, Koch GW, Peñuelas J, Hungate BA (2011) Responses of terrestrial ecosystems to temperature and precipitation change: a meta-analysis of experimental manipulation. Global Change Biol 17:927-942

Yepez EA, Scott RL, Cable WL, Williams DG (2007) Intraseasonal variation in water and carbon dioxide flux components in a semiarid riparian woodland. Ecosystems 10:1100-1115
Zak DR, Pregitzer KS, Curtis PS, Teeri JA, Fogel R, Randlett DL (1993) Elevated atmospheric $\mathrm{CO}_{2}$ and feedback between carbon and nitrogen cycles. Plant Soil 151:105-117

Zak DR, Blackwood CB, Waldrop MP (2006) A molecular dawn for biogeochemistry. Trends Ecol Evol 21:288-295

Zhuang Q et al (2004) Methane fluxes between terrestrial ecosystems and the atmosphere northern high latitudes during the past century: a retrospective analysis with a process-based biogeochemistry model. Global Biogeochem Cycles 18:GB3010

Zibilske LM, Bradford JM (2007) Oxygen effects on carbon, polyphenols, and nitrogen mineralization potential in soil. Soil Sci Soc Am J 71:133-139

Zimmer C (2010) The microbe factor and its role in our climate future. http://e360.yale.edu/feature/the_microbe_factor_and_its_ role_in_our_climate_future/2279/. Accessed 15 Dec 2015

Zimmerman L, Labonte B (2015) Climate change and the microbial methane banquet. Climate Alert, 27(1) http://www.climate.org/ publications/Climate\%20Alerts/2015summer/climatechangemi crobialmethanebanquet.Html. Accessed 15 Dec 2015

Zimov SA, Schuur EAG, Chapin FS III (2006) Permafrost and the global carbon budget. Science 312:1612-1613

Zolfagharifard E (2014) Mysterious microbes are speeding up climate change: new species is releasing huge amounts of methane, study finds. http://www.dailymail.co.uk/sciencetech/article2806725/. Accessed 15 Dec 2015 